\title{
Entrepreneurial organizing activities and nascent venture performance
}

\author{
Anna Long $\mathbb{B}^{\circ}$ Matthew S. Wood • \\ Daniel L. Bennett
}

Accepted: 21 December 2021 / Published online: 11 January 2022

This is a U.S. government work and not under copyright protection in the U.S.; foreign copyright protection may apply 2022

\begin{abstract}
This research provides an improved understanding of how ventures successfully organize via resource allocations. Conceptually, we apply elements of action theory to account for resource tradeoffs that occur as entrepreneurs make decisions about adding staff members to boundary spanning, technical core, and management functions. We then model how these allocation decisions differentially impact nascent venture performance. Empirically, we test our model with a sample of 2484 entrepreneurs captured in the Kauffman Firm Survey, a longitudinal dataset that tracks a random sample of US startups over an 8 -year period. Results from dynamic panel estimation reveal evidence of both performance penalties and performance boosts as the result of entrepreneurs
\end{abstract}

Supplementary Information The online version contains supplementary material available at https://doi. org/10.1007/s11187-021-00595-1.

A. Long $(\bowtie)$

Jack H. Brown Business College, California State University, San Bernardino, 7679 Dutch Loop,

San Bernardino, CA 92407, United States

e-mail: anna.long@csusb.edu

M. S. Wood

Hankamer School of Business, Waco, TX, USA

e-mail: ms_wood@baylor.edu

D. L. Bennett

College of Business, University of Louisville, Louisville, KY, USA

e-mail: daniel.bennett.2@louisville.edu adding staff to specific areas, revealing optimality in specific configurations of entrepreneurial organizing elements.

Plain English Summary A key implication of this study is that, in nascent ventures, resource allocation trade-offs must be made and how these are managed, via entrepreneur organizing decisions, is influential for venture performance. Specifically, we find that entrepreneurs should place a high priority on adding sales and production unit employees as these additions have a positive effect on performance. At the same time, they may place a lower priority on hiring non-owner management employees because such additions have a negative effect on performance.

Keywords Nascent firm performance .

Entrepreneurial organizing · Entrepreneurial hiring ·

Entrepreneurial action - Post venture creation .

System GMM

JEL Classifications $\quad$ L26 $\cdot$ D22 $\cdot$ M51 $\cdot$ M13 $\cdot$ C33

\section{Introduction}

The entrepreneurial journey is a winding road where through organizing, entrepreneurs acquire and allocate resources (Van de Ven et al., 1989), design organizational architecture and routines (Becker \& 
Gordon, 1966; Nelson \& Winter, 1982), and determine the boundaries of the firm (Santos \& Eisenhardt, 2009). These resource allocations, routine establishments, and boundary considerations are critical decisions in nascent ventures because some combinations may be more effective for venture viability and performance than others. While the literature on entrepreneurial organizing appreciates this, research to date has not given the relationship between organizing decisions and nascent venture outcomes much attention. Instead, it largely centers on how organizing unfolds as part of venture emergence via decisions that precede initial launch. This has resulted in a robust literature that has documented legitimizing activities (Delmar \& Shane, 2004), resource-assembly efforts (Brush et al., 2008), and planning initiatives (Liao \& Gartner, 2006), among others, as salient drivers of new venture formation.

While these insights are highly valued, the focus on organizing as a venture formation/emergence issue has created blind spots in our understanding of entrepreneurial organizing. One of them is that a key feature of nascent ventures is resource scarcity (Grichnik et al., 2014), and moving to the post founding era, it becomes clear that entrepreneurs can rarely optimally organize multiple firm activities at once. This puts pressure on entrepreneurs to discern links between variations in organizing activities and nascent venture performance, yet given the research to date, scholars are able to offer only limited insights. This unsolved puzzle is a concern because early-stage organizing decisions chart a course that "can persist for decades" (Simsek et al., 2015, p. 42), rendering understanding the performance effects of these decisions a critical need.

The present study addresses this need by conceptualizing entrepreneurial organizing activities as resource allocation trade-offs where different functional areas of nascent ventures are necessarily prioritized over others. From this base, we model how entrepreneurs' decisions toward those ends shape venture performance. Doing so requires new theoretical insights, and we derive them by drawing on conceptual features found in the organization action framework that was introduced by James Thompson (1967) and subsequently applied to aspects of emergent firms (e.g., Santos \& Eisenhardt, 2009; Smith \& Cao, 2007) and associated liability of newness dynamics (Singh et al., 1986). Thompson (1967) introduced firm activities in the technical core, boundary spanning, and management areas as three complementary, but at times competing, foci of organizational efforts. The technical core represents key operational tasks of production, boundary-spanning encompasses key interactions with constituents outside the organization, and management coordinates and mediates these activities. We elaborate on these in nascent ventures and consider them key components of entrepreneurial organizing, manifest as entrepreneurs' decisions to differentially hire staff into these areas, which impacts venture performance and does so differently in generalist firms (mix of product and service) versus specialist firms (product or service exclusively).

We empirically test our conceptualizations using a sample of 2469 entrepreneurs' leading nascent ventures (post-founding/emergence) captured in the Kauffman Firm Survey (KFS), a longitudinal dataset that tracks a random sample of US startups over an 8-year period. Using the System Generalized Method of Moments (SGMM) dynamic panel estimator (Blundell \& Bond, 1998), which allows us to address the endogeneity of strategic hiring decisions to venture performance (Hamilton \& Nickerson, 2003; Li et al., 2021), we examine how entrepreneurs' staff hiring decisions affect short-run nascent venture performance. We also test whether the performance effects of entrepreneurs' organizing decisions differ for generalist and specialist ventures.

Together, our theoretical insights and empirical findings make important contributions to the literature. First, we uniquely explore entrepreneurial organizing through the lens of Thompson's (1967) action framework, and this results in a new way of thinking about nascent venture entrepreneurial organizing as unfolding along the dimension of the technical core, boundary spanning, and management functions. Second, we move beyond the valuable but narrowly scoped notion that organizing activities are primarily a concern for firm formation (Brush et al., 2008; Delmar \& Shane, 2004) by documenting organizing as a feature that carries well past venture founding. In the vein, our longitudinal data uncovers previously overlooked patterns in the relationship between postemergence organizing activities and venture performance. Bridging this chasm, we provide new insights into how the entrepreneurial journey unfolds over time (McMullen \& Dimov, 2013). Third, by considering the role of differences between generalist and 
specialist ventures in the organizing and performance relationship, we reveal a previously undiscovered nuance where the consequences of resource allocation decisions in nascent ventures are a function of firm focus. While generalist versus specialist firm differences has long been a consideration in domains such as organization theory (cf., Freeman \& Hannan, 1983; Swaminathan, 2001), they have received limited attention in entrepreneurship, and we provide new understating in this regard.

\section{Conceptual Foundations}

\subsection{Entrepreneurial organizing}

Entrepreneurial organizing is the design, configuration, and implementation of elements such as resources, boundaries, and exchange within emergent and nascent ventures to create, develop, and deliver new products and services to the market (Gartner \& Starr, 1993; Katz \& Gartner, 1988). Entrepreneurial organizing embraces that as entrepreneurs introduce new offerings to the market, they are confronted with a wide array of possibilities for how to organize their ventures, seeking in principle, to land on configurations that are the most effective (Brush et al., 2008). At the same time, entrepreneurs face resource constraints (Stevenson \& Jarillo, 1990) that limit the range of activities that they can prioritize within organizing. We advance, then, that entrepreneurial organizing typically involves trade-offs between venture activities where certain areas are emphasized over others, with higher priority activities receiving greater resource allocations. Indeed, scholars have considered organizing activities to be a dynamic configuration where various elements are assembled in different ways (Birley, 1984; Brush et al., 2008)

It is notable, however, that the organizing research to date has focused almost exclusively on organizing as the antecedent to venture founding. These studies explore pre-emergence organizing, such as saving money to invest (Gatewood et al., 1995) and preparing a business plan (Reynolds, 2000), along with other activities that "lead to the emergence of new firms" (Lichtenstein et al., 2007, p. 236). In some cases, authors extend frameworks to explain organizing via dynamics such as activities that endow legitimacy (Manolova et al., 2012; Zimmerman \& Zeitz,
2002). While organizing as fuel for the emergence of new firms is fundamental, it is far from definitive because organizing occurs and is equally essential in the post-founding era. Only a few studies have considered the role of post-emergence organizing (i.e., early-stage ventures), generally focusing on business planning as the activity. These studies link planning to early-stage venture performance with mixed findings (Brinckmann et al., 2010; Gruber, 2007; Lange et al., 2007; Schwenk \& Shrader, 1993). While there may be many reasons for the equivocal results, we advance that activities such as "preparing a business plan" (Carter et al., 1996) tend to fade to the background post-founding as planning gives way to organizing.

In this vein, Katz and Gartner (1988) delineated organizing as centering on resources, boundaries (between venture and environment), and exchange (inputs/outputs). One organizing activity that touches each of these arenas and thus is likely to come to the fore in nascent ventures is the hiring of staff (Gatewood et al., 1995; Reynolds \& Miller, 1992). As Delmar and Shane (2004, p. 385) outline, entrepreneurs must "conduct product development, hire employees, seek funds" and the like, and these activities are "undertaken to different degrees." While each of the activities is essential, hiring uniquely spans multiple domains because employees take up key functions of the business, such as conducting research and development, making sales, and so forth. Further, hiring in nascent ventures is a multidimensional chess game because resource constraints mean that staffing to support one activity impacts the potential of other activities (Lichtenstein et al., 2007). The implication is that hiring represents a trade-off decision where the entrepreneur increases support for some activities while holding constant, or even dialing back, support for other activities. One arena where tradeoffs between different areas of organizational activities is a central focus is Thompson's (1967) theory of action, which addresses firm configuration in relation to mitigating uncertainties.

2.2 Learning from Thompson: technical core, boundary spanning, and managing

Thompson's (1967) seminal book “Organizations in Action" argues that firms mold their organizational structures in ways thought to mitigate 
external environmental uncertainties, and by allocating resources in this fashion, firms may enhance performance. Thompson (1967) highlights that firms must develop coordinated action to deal with highly uncertain environments, which are inherent in entrepreneurship (Alvarez \& Barney, 2007; McMullen \& Shepherd, 2006). These actions include production and activities related to "searching and learning as well as deciding" (Thompson, 1967, p. 9). Hence, Thompson points to the need for organizational structure design to account for the types of coordination required, and by extension, the types of job roles/ activities involved.

Thompson (1967) proposed three major types of job roles in organizations: technical core, boundary spanning, and managerial. The technical core represents key functioning units that perform the major tasks of the organization and includes the physical and intellectual tasks associated with producing a product or service. Boundary spanning involves the responsibility of interacting with agents outside the organization to carry knowledge and objectives to external constituents and bring back to the organization what is learned through boundary interactions (Weerts \& Sandmann, 2010). Those in the third category, managerial role, coordinate and mediate technical core and boundary spanning activities and, in doing so, gain knowledge and use it to decide future courses of action. Together, an optimal deployment and configuration of resources toward these roles are essential (Spender \& Kessler, 1995). Emphasizing managerial role, for instance, may lead to zeal in what Thompson (1967, p. 151) calls "opportunistic surveillance" in which firm leaders scan for chances to act, and these may prove to be smart moves or foolhearted "solutions in search of problem."

Thompson's technical core, boundary spanning, and managing breakdown of organizations have become a foundational framework. Scholars have used it to explain navigating the uncertainties of innovation (Spender \& Kessler, 1995) and to examine the role of boundary spanners as gatekeepers in facilitating discussion of innovation in terms of organization structure (Aldrich \& Herker, 1977), innovation process (Allen, 1977), networks (Friedman \& Podolny, 1992), and project performance (Tushman $\&$ Katz, 1980). More recent work links engagement in technical core and boundary spanning activities to firm performance within different organizational and contextual configurations (Pappas \& Wooldridge, 2007; Schotter \& Beamish, 2011). Together, these studies reveal the power of Thompson's insights for explaining innovative action, and therein, we believe Thompson's framework holds promise for the context of venturing (i.e., entrepreneurs leading their nascent firms). Prior research demonstrates the value of applying organization theories to entrepreneurship, where researchers apply what organization theorists view as a contextual factor (i.e., venturing manifest as startup/nascent firm) as a theoretical lever (cf., Navis \& Ozbek, 2016; Santos \& Eisenhardt, 2009; Younger $\&$ Fisher, 2020). We follow suit by bringing Thompson's (1967) action framework and its conceptual logic to bear in developing a new theory that explains resource allocation decisions embedded in entrepreneurial organizing. Specifically, we focus on entrepreneurs' decisions to hire staff into different areas of the venture as key organizing decisions, as illustrated in Fig. 1.

Hiring of staff represents an important juncture in the life of a nascent venture as adding employees lays the foundation for the capacity needed to become known as reliable and dependable, which is critical to gain the confidence and support of constituents (Aldrich, 1999; Liao et al., 2005; Parker \& Belghi$\operatorname{tar}, 2006)$. That said, employee hiring in nascent ventures is undertaken at different speeds, with different scales, and with employee tasks allocated in different ways (Brush et al., 2008; Reynolds \& Miller, 1992). Building on this, we leverage Thompson's (1967) action framework to address nascent venture hiring allocations, unlocking the ways in which allocations across boundary spanning, technical core, and managerial roles impact venture performance.

\section{Theory and Hypotheses}

One essential feature of nascent ventures that shapes the hiring and allocation of employees is resource scarcity. As Grichnik et al. (2014, p. 311) make clear, nascent firms must overcome a "lack of substantial managerial, financial, organizational, and physical resources." At the same time, entrepreneurs' encounter difficulty with organizing their nascent ventures to align scarce resources with objectives that are often blurred and unspecified (Garonne \& Davidsson, 2010). The net effect is that hiring staff in nascent 


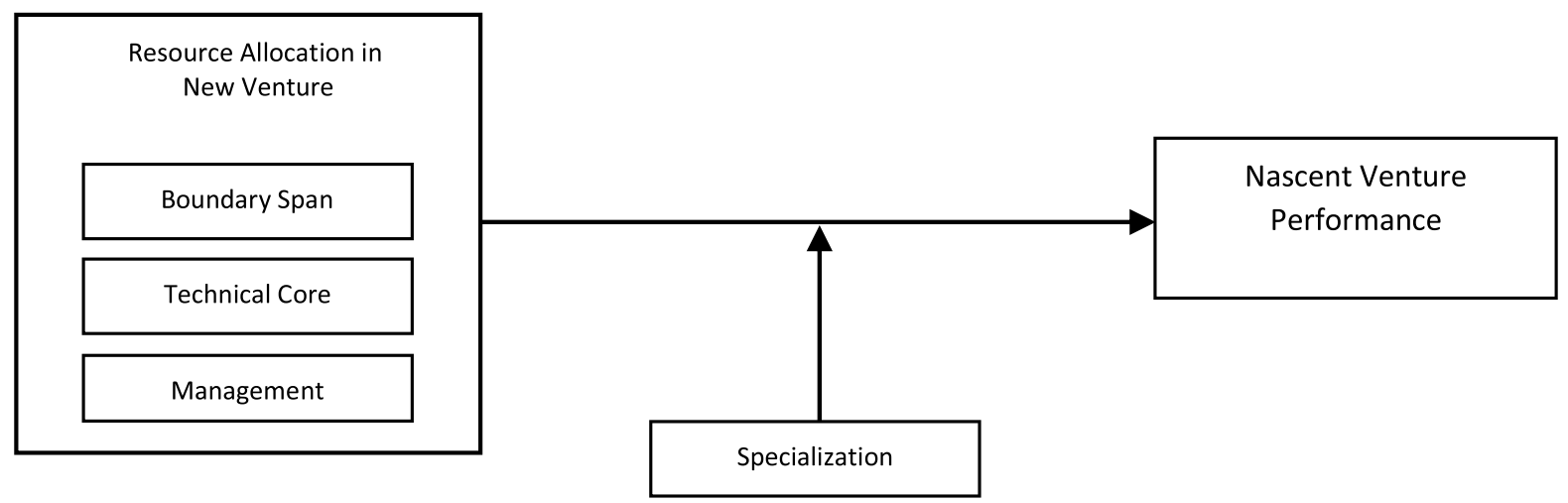

Fig. 1 Conceptual approach to entrepreneurial organizing and nascent venture performance

ventures represents an entrepreneurial judgment, under conditions of uncertainty, concerning the allocation of scarce resources towards their most highly valued use in seeking to satisfy an entrepreneur's objectives (Foss et al., 2019). We use the term allocation because resource constraints mean that trade-off decisions have to be made regarding which functional activity new hires will engage. Areas such as developing current or new offering(s), adding efficiency to internal production processes, and developing the capacity to provide enhanced customer service must be considered. Further, adding employees requires the presence and/or increases in an entrepreneur's managerial capacity to oversee the work of new hires. Thompson (1967) grappled with these issues, and his framework advanced that boundary spanning technical core, and managing represent key areas of the organization that may receive resource allocations, with each allocation decision representing a point of emphasis. We now explore effects on short-run performance as nascent ventures differentially add, through new hires, capacity to these areas, as illustrated in Fig. 2.

\subsection{Adding boundary span capacity}

Boundary spanning activities have been outlined by Thompson (1967) as those actions that engage external actors (e.g., prospective customers) in efforts to, among other things, facilitate transactions and in the process gather information about potential market opportunities. Sales staff are most often the employees who engage in these activities and therein, fulfill two main functions: external representation and internal information sharing and processing (Aldrich $\&$ Herker, 1977). We argue that, in nascent ventures, sales employees are charged with external representation. They facilitate communication between members or units within the venture and potential/ current customers in efforts to generate needed transactions (Onyemah et al., 2010). At the same time, sales representatives are responsible for interacting with constituents beyond the boundaries of the firm and "bring back" information from their interactions. Sales staff gain a sense of customer needs, competitor actions, and other dynamics. They convey these insights to firm founders or managers, who synthesize and interpret the information, link it to internal issues and plans, and make decisions in response (Aldrich \& Herker, 1977). In these ways, sales staff are critical for nascent ventures, and the entrepreneur's act of hiring sales representatives is the prioritizing of the external boundary-spanning role through resource allocation to this function.

By increasing boundary-spanning capacity via hiring sales representatives, their increasing numbers add to the volume of information gathered and shared. This, in turn, increases the rate of market and competitor intelligence transfer to internal units. This helps nascent ventures better understand their target customer, amplifies the sensing of competitive threats, and increases their ability to sense and tap unmet needs or changing trends in the market (Jackson \& Dutton, 1988; Sleptsov \& Anand, 2008). In parallel, increasing the number of sales representatives can build legitimacy and reputation for the nascent venture (Lounsbury \& Glynn, 2001; Überbacher, 2014; Tracey \& Dalpiaz, 2018). Having a visible and 


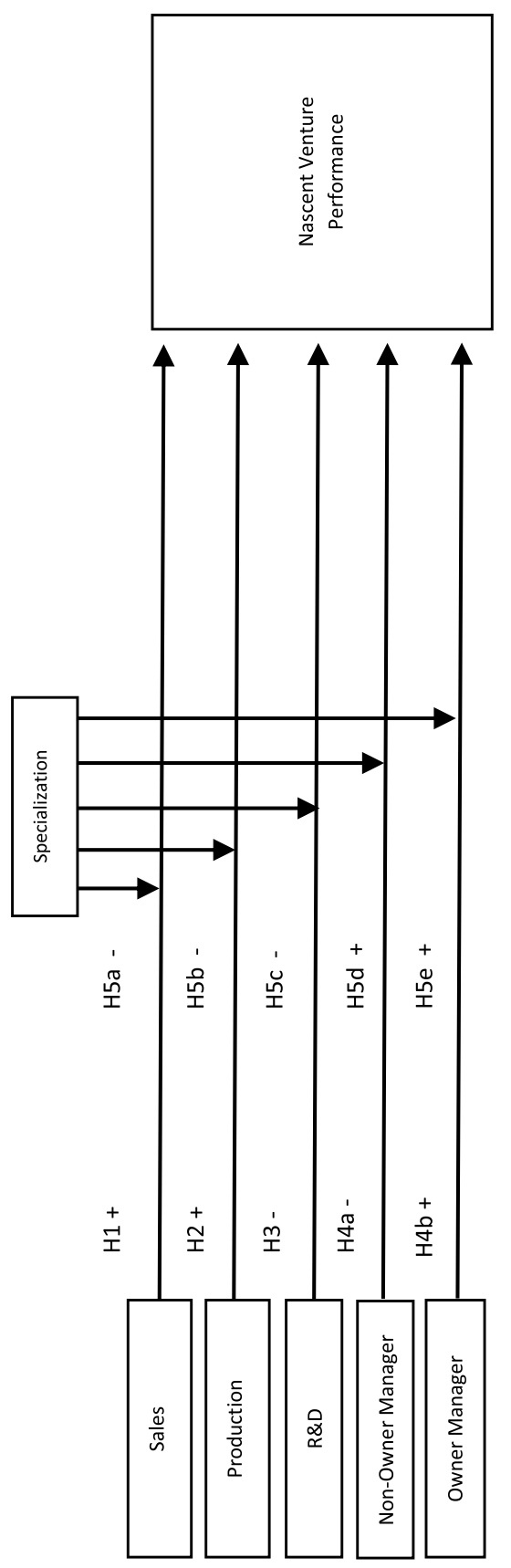

active sales force can signal to customers and other stakeholders that the nascent venture is robust in its efforts to reliably and confidently deliver its products and/or services. Because nascent ventures typically produce a limited set of offering(s) and sales staff tend to focus on narrow target markets, they tend to be visible to those who operate in the domain (Park \& Bae, 2004). This propels strong coordination between a nascent firm and its constituents, increasing the flow of transactions that contribute to firm performance. The sum of this logic leads to a first hypothesis:

Hypothesis 1: Nascent ventures that invest in hiring sales employees enjoy a positive performance effect.

\subsection{Adding technical core capacity}

Technical core activities represent the means of production for entrepreneurs to introduce and reliably deliver products/services to the market (Thompson, 1967). Staff hiring activity within the technical core bestows a nascent venture with additional capacity for the development and production of products/ services. Thus, two representative hiring activities in the technical core are the hiring of production staff, which primarily contribute to producing and delivering offerings to customers, and the hiring Research and Development (R\&D) staff who focus efforts on the tasks of further developing current offerings and/ or pursue the development of additional new offerings. We theorize the effects of adding staff to these areas in turn.

\subsubsection{Hiring production staff}

Production represents venture activities that generate and deliver valued products/services to customers (Shepherd \& Patzelt, 2013). Unlike established firms, a key challenge for nascent ventures is the construction of processes required to deliver a new, and in some cases visionary, offering to the market with high reliability and the capacity to scale (Pentland et al., 2012; Wood \& Mckinley, 2017). They must do this within resource and time constraints. Failure to deliver goods or services as promised severely undercuts venture prospects. Thus, hiring production staff is a critical consideration for entrepreneurs as doing 
so provides the technical core capacity needed to fulfill market commitments reliably.

Indeed, production in nascent ventures can vary in technical complexity (Daft, 1998; Kaynak, 2005) and in the degree of outsourcing utilized (Courpasson et al., 2016), but nevertheless, periods of initial experimentation in nascent ventures must eventually settle into patterns of predictable outputs. Prior research, including Thompson's (1967) action framework, document routinization as a frequent pathway for ventures to reliably produce and deliver product/ service to customers (Hannan \& Freeman, 1989; Nelson \& Winter, 1982). Therefore, a function of entrepreneurial organizing is developing routines that allow for stable production performance (Pagell et al., 2015), and to achieve this, nascent ventures must progress on the learning curve. The expansion of production staff increases a nascent venture's technical core capacity to routinize its operations and achieve production stability. Hence, when additional production staff are hired it emphasizes the technical core such that routinized processes are enabled, leading to an increased capacity for stable output production. This, in turn, bolsters nascent venture performance. Therefore, we propose the following hypothesis:

Hypothesis 2: Nascent ventures that invest in hiring production employees enjoy a positive performance effect.

\subsubsection{Hiring $R \& D$ staff}

An important aspect of nascent ventures is the design and development of the goods or services delivered to customers (Boyer \& Blazy, 2014; Tatikonda et al., 2013). The design and development function is typically handled by $R \& D$ staff. $R \& D$ is an essential function in organizations broadly, but it can be especially crucial for nascent ventures attempting to establish their offering(s) as distinct and/or superior to those currently available in the marketplace. At issue, however, is that an inherit complication of R\&D is high uncertainty. There are few assurances that investments in $R \& D$ will generate returns (Kothari et al., 2002). Thompson' (1967) framework suggests this is due, in part, to $R \& D$ requiring high coordination given its interdependent nature. That is, $\mathrm{R} \& \mathrm{D}$ is cumbersome because it requires coordination of expert and specialized knowledge, and in nascent ventures, such coordination and expertise are often limited (McGee et al., 1995). R\&D requires adjustments and pivoting to address technical issues and market feedback (Amabile, 1996; Xu et al., 2019). Therefore, in nascent ventures, entrepreneurs and their respective $R \& D$ staff must intensively communicate with each other, share knowledge, and jointly converge on development paths (Marschak \& Radner, 1972). These processes can be time-consuming and resource-intensive, and in the end, may not yield a viable output.

Hence, while adding to the technical core through hiring $R \& D$ staff provides the capacity to develop current or future offerings more readily, there is not a direct line to firm performance in the way there is with adding production staff (Kothari et al., 2002). Ultimately, "entrepreneurs who invest in R\&D projects face the technical uncertainties associated with completing the project, and these are idiosyncratic and inherently unhedgeable" (Whalley, 2011, p. 413). The uncertainty of R\&D does not mean that it cannot or will not pay off as there are indeed nascent ventures that effectively capitalize on R\&D efforts (e.g., McGee \& Dowling, 1994). Yet on average, nascent firms struggle to capitalize on R\&D. Prior research offers rather compelling evidence that economic returns on R\&D tend to be skewed toward a few "big hits" (Grabowski \& Vernon, 1994) which glosses over the reality that a great many firms experience "dissatisfaction with the low returns on their R\&D investments" (Ravichandran et al. (2017), p. 812).

The low return on $R \& D$ has been a problem has been documented as flowing from, among other things, the firm's inability to develop complimentary capabilities that enable R\&D efforts, such as "engaging customers in innovation activities, exploiting external ideas, managing huge amounts of data" and the like (Ravichandran et al., 2017, p. 812, citing El Sawy et al., 2016, Jaruzelski \& Dehoff, 2010, Leiponen \& Helfat, 2010). Developing R\&D complementary capabilities is especially challenging in nascent firms, given resource constraints. Add to this, there is a high degree of entrepreneurial skill needed in nascent firms to effectively convert R\&D efforts 
into enhanced venture performance (Michelacci, 2003), and such skill is often in short supply. ${ }^{1}$

This does not mean that R\&D is not valuable for nascent ventures, but rather its efficacy is highly variable (Ravichandran et al., 2017). R\&D staff must process a large amount of information from users, customers, and even outside technical experts and synthesize it into the development of the product/ service. This can result in confusion, interpretive missteps, technical impossibilities, and overengineering that can block or create errors in product/service offerings (March, 1991; Musaji et al., 2019). Therefore, entrepreneurial organizing in nascent ventures toward $R \& D$, through adding $R \& D$ staff, will tend to experience a negative performance effect. This suggests the third hypothesis.

Hypothesis 3: Nascent ventures that invest in hiring $R \& D$ employees suffer from a negative performance effect.

\subsection{Adding management capacity}

Another option for entrepreneurial organizing is to focus on increasing formal coordination and control capabilities by hiring management staff. As entrepreneurs move their nascent ventures forward, they develop the "know-how" to optimally organize the venture (Argote \& Miron-Spektor, 2011). But this knowledge, if held by the entrepreneur alone, is tacit such that access to it by various stakeholders is limited (Ambrosini \& Bowman, 2001; Hayek, 1945), placing limits on the venture's ability to optimize. To address this, entrepreneurs impose formal organization structures on their nascent ventures and therein, bring in manager(s) to run daily operations. This is useful on several fronts in relation to organizing. First, the addition of management staff injects the

\footnotetext{
${ }^{1}$ Note that R\&D is not always conducted simply for economic returns. Firms engage in $R \& D$ even when they know the activity may be a cost center, rather than a revenue driver, because conducting $R \& D$ allows ventures to have the technical expertise to leverage spillover knowledge and therein better work with key suppliers, understand new developments in the market, and in some cases reverse engineer competitor offerings (Cohen \& Levinthal, 1994; Rodríguez-Pose and Crescenzi, R., 2008).
}

nascent venture with hierarchical coordination, which is a known approach to address innovation to market issues such as production problems (Bonaccorsi \& Rossi, 2003). Second, managers increase the capacity to "evaluate and select routines from among the most promising ones," and they educate and guide workers to follow routines that help with "organizing the emergent ventures' cooperative behaviors" (Aldrich \& Yang, 2014 p. 69). Moves in this direction represent what Burns and Stalker (1961) and Thompson (1967) articulate as a shift from organic structure to a more mechanistic structure.

As this shift unfolds, there is recognition that the management role is nuanced because some managers have an ownership stake in the firm while others do not. ${ }^{2}$ Distinguishing between these two classes of managers is useful because when it comes to management capacity in nascent ventures, both coordination issues (as discussed above) and managerial alignment issues come into play. Prior research has long discussed the problems that arise when one party (e.g., manager) acts on behalf of another (entrepreneur/ owner) in ways that misalign, engaging actions that favor what is best for the employee over what is best for the owner(s) (e.g., Jensen \& Meckling, 1977). While such self-interest seeking by employees can happen, in nascent ventures, it is often not as pressing of a concern as another misalignment issue: differences in access, processing, and use of information. Agency theory research has documented that when it comes to the employee-owner dyad, asymmetries can form as employees withhold information from owners (Arrow, 1984; Mishra et al., 1998). In the case of nascent ventures, however, the problem tends not to be so much one of withholding information as it is one of the differences in attention toward and use of specific information, such that owners often attend to and emphasize different aspects of business-related information than do employees. This is what is known as a "preference" or principal-agent problem in which hired managers do not exhibit the same preferences in attention and related ways of operating that owners do (Shapiro, 2005).

Applied to the action framework (Thompson, 1967), preference problems serve as an additional

\footnotetext{
${ }^{2}$ We thank an astute reviewer for pointing this out and recommending this consideration.
} 
explanation for why there is likely to be a negative relationship between entrepreneurs hiring employeemanagers and firm performance. That is, employee managers do not reflect the owners' attentional, informational, and operation preferences. This might be because managers' personal incentives are not wellaligned with owner preferences, or because of a selection hazard where the employee-manager lacks the skills to adopt owner preferences, but regardless the net effect is that employee-managers are unable to execute venture operations with the same efficacy as owners. One solution for this is to remove the alignment gap by having owner-managers, rather than employee managers, lead venture activities. In other words, instead of hiring traditional wage-paid managers, the venture can instead provide an equity ownership stake in return for management skill and effort (Jensen \& Murphy, 1990; Mehran, 1995).

Admittedly, entrepreneurs are often reluctant to give up equity, and thus adding owner-managers is not the most common approach, but the reason for doing so is an increased chance that owner-manager additions will adopt an "owner mindset" where the most effective practices are utilized. Audretsch et al.'s (2009), p. 153) nicely encapsulate this logic, noting that in nascent ventures, "equity ownership may not only serve as a mechanism to ensure managerial effort (Jensen \& Meckling, 1977), it also provides incentives to make firm-specific investments beyond their managerial expertise." Hence, we contend that as firms increase the number of owner-managers, they experience improvements in the coordination of activities needed to boost nascent venture performance. This logic is reflected in the following hypothesis:

Hypothesis 4alb: Distinguished by owner status, nascent ventures that add a) non-owner managers suffer from a negative performance effect, while those that add b) owner-managers will enjoy a positive performance effect.

\subsection{Moderating role of specialization}

A final element of our conceptual model is the integration of the role of venture specialization. By this, we mean whether a nascent venture is a generalist firm that introduces a mix of product and service offering(s) or is a specialist firm that focuses exclusively on product or service offering(s). While specialization can be delineated in different ways, we follow research that cites differences between the way product and service firms evolve (Avlonitis et al., 2001; Brentani, 1991; Zeithaml, 1981). Specifically, services are demarcated from products by their intangible, simultaneously produced and consumed nature (Johne \& Storey, 1998). This renders certain elements central for service firms. There is, for example, greater pressure on service firms to "interact with potential users" (Alam, 2002, p. 25), resulting in an increased need for "employee involvement" to account for the customer-centric nature of services (Vermeulen et al., 2005, p. 692). These differences are impactful because they increase complexity and fuel coordination demands for nascent firms that introduce a mix of products and services. Entrepreneurs who build their ventures exclusively on products or services face a less complex task environment (Dess \& Beard, 1984) and, therein, can tailor firm activities and resource deployments with a singular, and presumably more efficient, focus.

Applied to our study, we advance that nascent firms whose product or service specialize will experience different performance effects from staff hiring decisions than those ventures that generalize (mix of products and services). This is because when it comes to allocation of staff to the technical core, boundaryspanning, or management realms (Thompson, 1967), whether a nascent venture is product or service specialized influences how those resources are utilized. New service introductions, for example, tend to focus on making minor pivots and do not require a high level of R\&D activities (Tamura et al., 2005), while new product introductions tend to involve innovations that require R\&D (Johne \& Storey, 1998). Firms that specialize can adjust accordingly, whereas firms that generalize must balance these competing demands, not just with $R \& D$ but also with the management of firm activities.

At the same time, while a specialist venture hones a specific market domain (Park \& Bae, 2004), a generalist venture that offers both products and services faces an expansive market domain and, therein, additional contingencies (Metters \& Vargas, 2000). This is an issue for boundary spanning because there are "more contingencies than boundary spanners can keep under surveillance" (Thompson, 1967, p. 133). As we argued above, sales 
staff are key boundary spanners, and an expansive domain of mixed offerings renders sales staff unable to gather and communicate information back to the venture with the same efficiency as those in specialized firms. Finally, the hiring of production staff plays differently in specialist versus generalist firms. These workers are charged with transforming domain-specific knowledge that boundary spanners bring back to the firm, and this knowledge creation process tends to be more fragmented in generalist ventures ( $\mathrm{Li}$ et al., 2009). The net effect is that in mixed offering ventures, convergence around aspects of production can be slow as customer and supplier requirements are incorporated (Schilling \& Hill, 1998), rendering increases in production staff less effective.

When it comes to R\&D and management, we reiterate that ventures who specialize face a less complex task environment. This allows them to tailor R\&D such that they are better able to develop complementary capabilities that enable $R \& D$ efforts, such as coordination with outsiders whereby they can "engage customers in innovation activities" because they have a more focused audience (Ravichandran et al., 2017, p. 812). This renders the hiring of $R \& D$ staff more effective, weakening the performance penalty when firms specialize. While this is a positive effect from specialization, things change when it comes to hiring management because specialization further encourages adoption of more mechanistic structures that inhibit the flexibility needed to address the shifts nascent ventures commonly experience (Spender \& Kessler, 1995). In specialized firms, managers tend to become taskfocused, and this narrows their field of vision when it comes to coordination and the need to engage in boundary spanning activities (Thompson, 1967) that allow ventures to sense changes in the market and adapt accordingly. Hence, we theorize that specialist firms will receive a greater performance boost from the increased alignment that comes from adding owner-managers, while the negative effect of adding non-owner managers will be amplified.

Taken together, these elements of entrepreneurs' staff hiring decisions reflect differential effects depending on whether the nascent venture is a generalist or specialist firm. These effects are reflected in the following set of hypotheses:
Hypothesis 5alblcldle: Specialization (product or service focus) moderates the relationship between nascent venture employee hiring decisions and firm performance. As compared to generalist ventures, specialized ventures realize a stronger positive performance effect from hiring (a) sales staff, a weaker positive performance effect from hiring (b) production staff, a weaker negative performance effect from hiring (c) R\&D staff, and a stronger negative performance effect from hiring (d) only non-owner management staff, while a stronger positive performance effect from (e) only owner-management staff.

\section{Data and Methodology}

\subsection{Dataset}

We use the KFS, a longitudinal dataset that tracks a random sample of 4928 US nascent ventures over an 8 -year period. The KFS sample was randomly drawn from the cohort of new ventures founded in 2004 from the Dun and Bradstreet database ${ }^{3}$. The sample of ventures was surveyed annually until 2011. The dataset contains information on firm-level characteristics and founder attributes. Firm-level information captured includes the firm's legal form, number, and types of employees, the number of founders, revenue, assets, expenses, industry, equity, and debt financing. For the founder level of information, the datasets report gender, education, and years of work experience for each founder (Robb et al., 2009; Robb \& Watson, 2012).

\footnotetext{
3 To derive their sample, Farhat and Robb (2018) first drew a random sample of more than 250,000 newly formed businesses. To be eligible for the sample, a firm must have satisfied at least one of the following conditions for the first time in 2004: (a) Obtained an employer identification number; (b) Used Schedule C or Schedule C-EZ to report either income from the business or personal income tax when trading as a sole proprietor; (c) Reported making state unemployment insurance payments; or (d) Reported making federal insurance contribution act payments. Three types of businesses were excluded from their sample: (1) those started as a branch or subsidiary of an existing business; (2) inherited businesses; and (3) not-for-profit organization. These selection criteria yielded a final unweighted sample of 4928 newly formed, independent ventures.
} 
We chose the KFS dataset for several reasons. First, the KFS is a longitudinal dataset with records of a large number of ventures in the USA over an 8-year period from 2004 to 2011, providing us with sufficient time duration to observe how organizing activities unfold and influence firm performance. Second, the KFS includes information on post-establishment new venture performance. All firms are created at the same time (i.e., 2004), but performance is recorded in each subsequent year. Third, the KFS offers details on organizing activities (Farhat \& Robb, 2018), particularly on the categorization of the types of hiring activities into specified units. Additionally, the KFS provided information on many influential exogenous variables (e.g., information on intellectual property, legal status, firm location, etc.) that we include as control variables. Due to missing data, our final sample consists of an unbalanced panel of 2484 nascent ventures and 11,802 firm-year observations.

\subsection{Dependent variable}

Our dependent variable is nascent venture performance, and we operationalize it as revenue. Following previous entrepreneurship research (Campbell et al., 2012; Eisenhardt \& Schoonhoven, 1990; Gruber et al., 2008; Murphy et al., 1996), we use revenue as our measure of nascent venture performance because it is the first indicator that a new venture has successfully marketed its products and services to paying customers (Dencker \& Gruber, 2015). Using the CPI-U index, we adjusted the raw revenue data to constant 2011 figures to account for inflation. We then transformed real revenue using the inverse hyperbolic sine (IHS) transformation ( $\tilde{r e v}=\operatorname{arcsinh}(r e v)=\ln \left(r e v+\sqrt{r e v^{2}+1}\right)$ ) for two reasons. First, revenue is highly skewed such that it needs to be transformed to better approximate a normal distribution and reduce the effect of outliers. Second, our sample contains a large number of zeros (i.e., 1828 or $15.9 \%$ of our 11,521 observations are zero), and the IHS transformation retains zero-valued observations, which may be economically meaningful (Bellemare \& Wichman, 2020).

\subsection{Independent variables}

Our study is concerned with a better understanding of how nascent venture hiring decisions influence firm performance. Specifically, we examine five different employment categories: (1) Sales Employment; (2) Production Employment; (3) R\&D Employment; (4) Non-Owner Management Employment; and (5) Owner Management Employment as proxies to measure a new venture's boundary span, technical core, and management capacity. We measure all five variables as the number of employees in each category in a given year.

In testing $\mathrm{H} 1$, we use the number of sales employees as a proxy for the boundary span capacity. This follows prior studies that generally agree, sales staff is a strong representation of boundary spanning as the activities of sales personnel connect the firm and customer (Aldrich \& Herker, 1977; Lysonski \& Johnson, 1983; Wyld, 2010). For H2 and H3, we use the number of production personnel and the number of R\&D personnel as proxies for the technical core capacity. Prior research has indicated that the capacity of a production unit represents a new venture's technical core capacity in terms of effectively allocating resources into producing and delivering products/services to the market (Tatikonda et al., 2013). On the other hand, in justifying a firm's capacity in innovating new products and/or services, we observe that researchers who study innovation generally agree that ventures acquire new knowledge by hiring new R\&D employees (Müller \& Peters, 2010; Niebuhr, 2006). Thus, following Mann and Sanyal (2010), in using the number of R\&D personnel, we use a similar measure as a proxy for a firm's R\&D (technical) capacity. Finally, following Grimpe et al. (2019), we use the number of employee managers and the number of owner-managers to test $\mathrm{H} 4 \mathrm{a}$ and $\mathrm{H} 4 \mathrm{~b}$.

\subsection{Moderator variables}

Prior studies in specialization have operationalized the measure for business model focus in terms of aircraft types (Claussen et al., 2018) or car engine types (Dobrev et al., 2001; Dobrev et al., 2002). We adopt a similar operationalized strategy and measure the specialization in a nascent venture in terms of three categories-generalization, product-focus, and service focus. We contend that specialization moderates the performance effects of nascent venture employee hiring decisions. We conceptualize specialization as product or service focus, which we measure using two dummy variables. First is Product-Focus, 
a dummy variable equal to one if a firm exclusively offers products for sale, and zero otherwise. Second is Service-Focus, a dummy variable equal to one if a firm exclusively offers services for sale, and zero otherwise. Our baseline omitted category is generalization, which includes nascent ventures that offer both products and services.

\subsection{Control variables}

We control for a large number of variables that potentially affect firm performance. First is a set of characteristics of the primary entrepreneur, including: Age and Age-Squared; number of years of work experience (Experience); a dummy variable equal to 1 if the entrepreneur has at least a bachelor's degree and 0 otherwise (Education); and dummy variable equal to 1 if the entrepreneur has started at least two other businesses (Serial Entrepreneur). Second is a set of founding team characteristics, including: the share with US citizenship (Citizenship Share) and its Gender Diversity and Cultural Diversity. We measure the two diversity variables using Blau's (1977) index.

Third, we control for a set of firm-level factors, including: the hours worked by owner employees (Owner Hour Share); a dummy variable indicating whether the firm has a patent (Intellectual Property); the value of a firm's investment capital, adjusted for inflation and transformed using the IHS function to account for the large number of zeros (i.e., 70\% of observations) and skewed nature of the data (Investment); and a dummy variable equal to 1 if the firm is a home-based business and 0 otherwise (Home-Based Business). Lastly, we control for the target market of a firm's offerings by including three dummy variables equal to 1 if a firm markets its products and services regionally (Regional Market), nationally (National Market), and internationally (International Market). Table 1 describes the variables included in our analysis, as well as provides summary statistics. We present a correlation matrix in Table 2.

\subsection{Methodology}

We estimate the effect of employee hiring decisions on nascent venture performance for a sample of 2484 startups over the period 2004-2011 using the System Generalized Method of Moments (SGMM) dynamic panel estimator (Arellano \& Bover, 1995; Blundell
\& Bond, 1998), a method increasingly used in longitudinal entrepreneurship studies (Bennett, 2019a, b; Croce et al., 2013; Tran, 2019). SGMM is an appropriate choice for our analysis for several reasons. First, the process by which our DV (i.e., revenue) is generated is likely dynamic (i.e., firm revenue has a high degree of persistence such that revenue in period $t$ is strongly correlated with revenue in period $t-1$ ). As such, a dynamic panel model that controls for this persistence in firm revenue is needed. SGMM avoids the Nickell (1981) autocorrelation bias that arises from controlling for lagged values of the DV and unobserved, time-invariant firm heterogeneity in the same equation.

Second, hiring decisions by entrepreneurs are strategic decisions that are endogenous to firm performance (Hamilton \& Nickerson, 2003). Typical regression methods (i.e., Ordinary Least Squares) fail to correct for this simultaneity bias, leading to biased coefficient estimates and potentially faulty statistical inference about hypotheses (Wooldridge, 2010). SGMM corrects for this source of endogeneity using internal instrumental variables, allowing for causal estimates (Bascle, 2008). More specifically, SGMM provides a weighted estimates from a system of two equations, including: (i) a first-difference equation that uses lagged levels of the endogenous variables as instruments; and (ii) a level equation that uses lagged differences of the endogenous variables as instruments (Arellano \& Bover, 1995; Blundell \& Bond, 1998). ${ }^{4}$ Lastly, our dataset includes 2484 firms observed over an 8-year period, and SGMM is appropriate for panels with a large cross-sectional sample and small-time dimension (Bennett, 2019b).

For our main analysis, we estimate Eq. 1 using the Stata command xtabond2 (Roodman, 2009b), where $\operatorname{Rev}_{i, t}$ is revenue for firm $i$ in period $t$; Employ $_{i, t-1}$ is a matrix of employment variables (i.e., sales, R\&D, production, management) for firm $i$ in period $t-1 ; X_{i, t}$ is a matrix of control variables for firm $i$ in period $t$; $\theta_{i}$ and $T_{t}$ denote firm and period fixed effects; $\epsilon_{i, t}$ is an

\footnotetext{
${ }^{4}$ Due to the unbalanced nature of our dataset, we use forward orthogonal deviations as instruments in lieu of lagged differences for the level equation (Arellano \& Bover, 1995; Roodman, 2009b).
} 
Table 1 Variable descriptions and summary statistics

\begin{tabular}{|c|c|c|c|c|c|}
\hline Variable & Description & Mean & SD & Min & Max \\
\hline Revenue & $\begin{array}{l}\text { Annual firm revenue, transformed using inverse hyperbolic sine (IHS) func- } \\
\text { tion. }\end{array}$ & 9.36 & 4.77 & 0.00 & 20.37 \\
\hline Sales employment & Number of sales employees. & 0.96 & 3.12 & 0.00 & 100.00 \\
\hline Production employment & Number of production employees. & 0.87 & 3.71 & 0.00 & 100.00 \\
\hline R\&D employment & Number of R\&D employees. & 0.58 & 1.77 & 0.00 & 100.00 \\
\hline Owner manager & Number of owners who are also management employees. & 1.35 & 0.84 & 0.00 & 15.00 \\
\hline Non-owner manager & Number of management employees who are not the owner. & 0.40 & 2.17 & 0.00 & 198.00 \\
\hline Product-focus & Dummy variable $=1$ if firm only markets products, 0 otherwise. & 0.14 & 0.35 & 0.00 & 1.00 \\
\hline Service-focus & Dummy variable $=1$ if firm only markets services, 0 otherwise. & 0.53 & 0.50 & 0.00 & 1.00 \\
\hline Age & Age of primary entrepreneur. & 47.55 & 13.50 & 0.00 & 103.00 \\
\hline Education & $\begin{array}{l}\text { Dummy variable }=1 \text { if entrepreneur has at least a college education, } 0 \text { other- } \\
\text { wise. }\end{array}$ & 0.58 & 0.49 & 0.00 & 1.00 \\
\hline Experience & Number of years of work experience of entrepreneur. & 13.53 & 11.01 & 0.00 & 60.00 \\
\hline Serial entrepreneur & $\begin{array}{l}\text { Dummy variable }=1 \text { if entrepreneur has started at least } 2 \text { other businesses, } 0 \\
\text { otherwise. }\end{array}$ & 0.21 & 0.41 & 0.00 & 1.00 \\
\hline Gender diversity & Blau's index of gender diversity of founding team. & 0.08 & 0.18 & 0.00 & 0.50 \\
\hline Cultural diversity & Blau's index of racial diversity of founding team. & 0.02 & 0.09 & 0.00 & 0.67 \\
\hline Citizenship share & Share of active owner-operators who are US citizens. & 0.97 & 0.15 & 0.00 & 1.00 \\
\hline Owner hour share & Active owner-operator hours as share of all employee hours. & 37.07 & 21.52 & 0.00 & 120.00 \\
\hline Intellectual property & Dummy variable $=1$ if firm has a patent, 0 otherwise. & 0.21 & 0.41 & 0.00 & 1.00 \\
\hline Investment & Value of all sources of financial investment, transformed using IHS function. & 2.91 & 4.58 & 0.00 & 17.20 \\
\hline Home-based business & Dummy-variable $=1$ if home-based business, 0 otherwise. & 0.53 & 0.50 & 0.00 & 1.00 \\
\hline Regional market & Dummy variable $=1$ if firm markets products/services regionally, 0 otherwise. & 0.01 & 0.12 & 0.00 & 1.00 \\
\hline National market & Dummy variable $=1$ if firm markets products/services nationally, 0 otherwise. & 0.01 & 0.11 & 0.00 & 1.00 \\
\hline International market & $\begin{array}{l}\text { Dummy variable }=1 \text { if firm markets products/services internationally, } 0 \\
\text { otherwise. }\end{array}$ & 0.02 & 0.15 & 0.00 & 1.00 \\
\hline Observations & 11,802 & & & & \\
\hline Number of startups & 2484 & & & & \\
\hline
\end{tabular}

idiosyncratic error term; and $\beta$ is a parameter vector that captures the main effects of our independent variables of interest. to our DV (i.e., revenue) to account for the skewness and large number of zeros in our dataset, interpretation of the coefficient estimates is not straightforward.

$\operatorname{Re}_{i, t}=\alpha_{o}+\sum_{j=1}^{2} \alpha_{j} \operatorname{Re} v_{i, t-j}+$ Employ $_{i, t-1}^{\prime} \beta+X_{i, t}^{\prime} \gamma+\theta_{i}+\nu T_{i}+\epsilon_{i, t}$

Before presenting our results, we first highlight that we adopt best practices recommended by Wennberg et al. (2019) on reporting and discussing our empirical findings. First, we omit asterisk from our tables. Second, we report exact $p$ values and 90\% confidence intervals for our independent variables. Third, we interpret the effect sizes of our independent variables. Because we applied the IHS transformation
We, therefore, derived semi-elasticities for our independent variables by applying the hyperbolic sine transformation of our coefficient estimates, $\hat{\beta}$, and multiplying by $\frac{E m p l o y}{R e v}$. More specifically, we used the Stata command nlcom to derive the Eq. 2, where $\xi$ is the elasticity and $\overline{R e v}$ and $\overline{\text { Employ }}$ denote the sample means of firm revenue and the respective employment variable (Bellemare \& Wichman, 2020). 


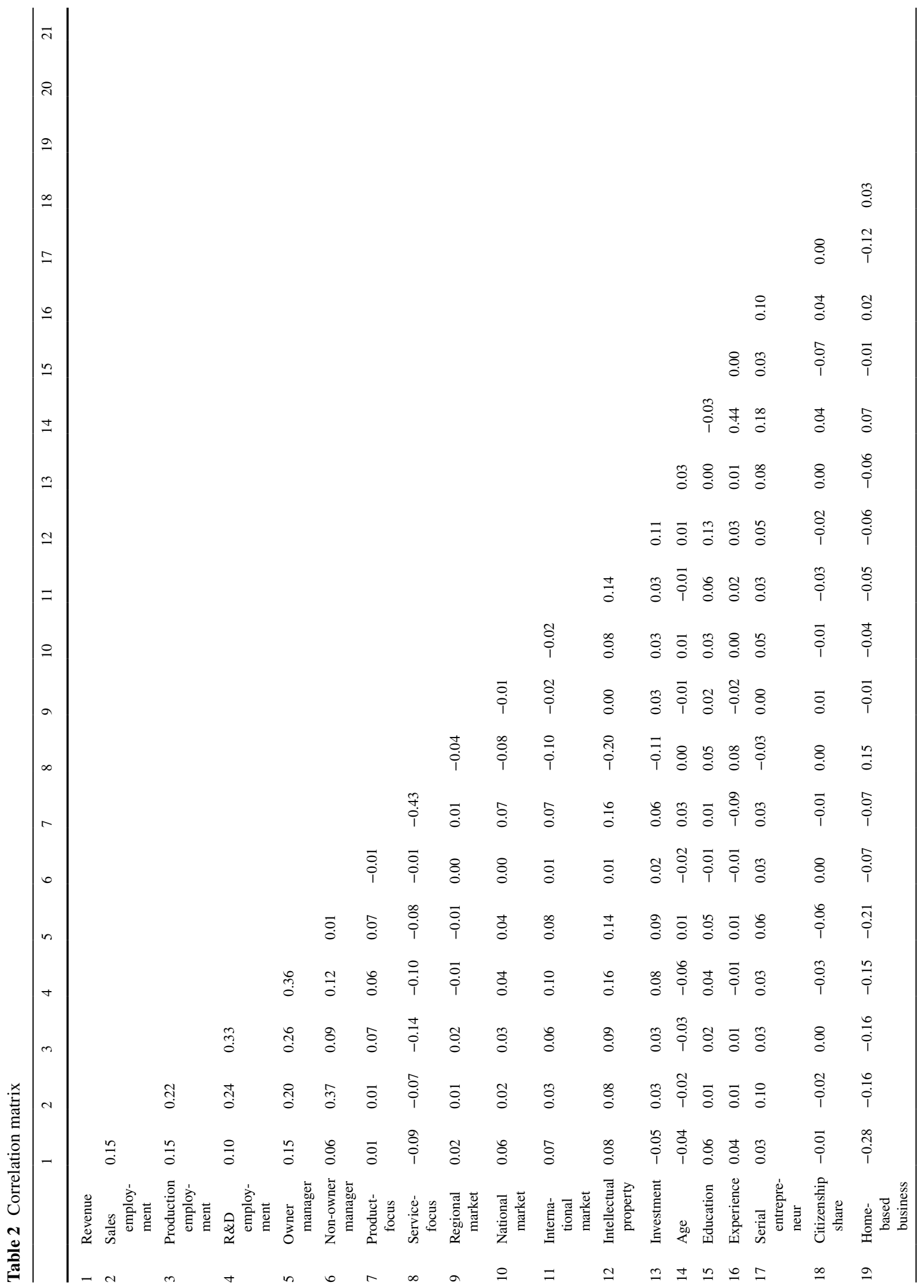


$\xi=100 \cdot\left[\hat{\beta} \cdot\left(\overline{\text { Employ }} \cdot \frac{\sqrt{\overline{\operatorname{Rev}}^{2}+1}}{\overline{\operatorname{Rev}}}\right)\right]$

Next, because we utilize observational data, we address two potential sources of endogeneity. First is potential simultaneity bias. That is, in addition to hiring decisions influencing firm performance, it is conceivable that firm performance influences hiring decisions. As described above, we employ SGMM, an instrumental variable method that utilizes lagged values of endogenous variables as instrumental variables to address this issue ( $\mathrm{Li}$ et al., 2021). Second is potential survivorship bias attributable to firm attrition over the longitudinal survey period (Cader \& Leatherman, 2011). That is, if the final sample of firms that remain in the KFS for the duration of the survey period differs systematically from the original sample of firms (Dosi et al., 2017), resulting estimates may suffer from a form of sample selection bias (Certo et al., 2016; Heckman, 1979). Fortunately, the KFS authors (Farhat \& Robb, 2018) addressed this issue at the outset of their survey by oversampling and recalculating probability weights for each successive survey wave. These weights allow analysts to account for the failure of nascent ventures and their permanent exit from the longitudinal dataset (for more information, see Farhat \& Robb, 2014). We follow Dosi et al. (2017) in using the KFS probability weights from the final period in our estimations. $^{5}$

Finally, we treat as endogenous the following variables: the two lagged values of our DV (i.e., firm revenue); our five independent variables (i.e., sale, production, R\&D, and owner and nonowner management employment); product-focus and service-focus; and our target market variables. To reduce potential issues of autocorrelation and instrument proliferation, which can invalidate results, we collapse the instrument matrix and

5 As a robustness check, we also estimate our model using the Heckman (1976) two-step method (Bascle, 2008; Hamilton \& Nickerson, 2003). See Sect. 5.3 for more details. 
Table 3 Effects of new venture hiring decisions on performance

\begin{tabular}{|c|c|c|c|c|c|c|}
\hline \multirow[b]{2}{*}{ Lagged DV } & \multicolumn{3}{|l|}{ (1) } & \multicolumn{3}{|l|}{ (2) } \\
\hline & Coef & SE & $p$ & Coef & SE & $p$ \\
\hline Revenue, 1-year lag & 0.550 & 0.191 & 0.004 & 0.222 & 0.021 & 0.000 \\
\hline Revenue, 2-year lag & 0.099 & 0.113 & 0.381 & 0.090 & 0.017 & 0.000 \\
\hline \multicolumn{7}{|l|}{ Main effects } \\
\hline Sales employment & 0.043 & 0.026 & 0.090 & 0.055 & 0.016 & 0.001 \\
\hline Production employment & 0.045 & 0.023 & 0.052 & 0.088 & 0.051 & 0.083 \\
\hline R\&D employment & -0.043 & 0.063 & 0.494 & -0.114 & 0.088 & 0.195 \\
\hline Owner management & -0.016 & 0.138 & 0.910 & 0.167 & 0.199 & 0.403 \\
\hline Non-owner management & -0.090 & 0.047 & 0.054 & 0.122 & 0.123 & 0.320 \\
\hline \multicolumn{7}{|l|}{ Moderators } \\
\hline Product-focus & -0.413 & 0.345 & 0.231 & -0.806 & 0.524 & 0.124 \\
\hline Service-focus & 0.015 & 0.255 & 0.948 & 0.110 & 0.377 & 0.771 \\
\hline Product-focus*sales & & & & 0.256 & 0.132 & 0.053 \\
\hline Product-focus*production & & & & -0.028 & 0.054 & 0.608 \\
\hline Product-focus $*$ R\&D & & & & 0.125 & 0.154 & 0.415 \\
\hline Product-focus*owner management & & & & 0.084 & 0.288 & 0.771 \\
\hline Product-focus*non-owner management & & & & -0.456 & 0.307 & 0.138 \\
\hline Service-focus*sales & & & & 0.020 & 0.033 & 0.535 \\
\hline Service-focus*production & & & & -0.075 & 0.058 & 0.195 \\
\hline Service-focus*R\&D & & & & 0.099 & 0.105 & 0.346 \\
\hline Service-focus* owner management & & & & -0.105 & 0.201 & 0.601 \\
\hline Service-focus*non-owner management & & & & -0.217 & 0.130 & 0.095 \\
\hline \multicolumn{7}{|l|}{ Entrepreneur controls } \\
\hline Age & 0.033 & 0.011 & 0.003 & 0.055 & 0.014 & 0.000 \\
\hline $\mathrm{Age}^{\wedge} 2$ & 0.000 & 0.000 & 0.005 & -0.001 & 0.000 & 0.000 \\
\hline Education & 0.369 & 0.138 & 0.008 & 0.642 & 0.126 & 0.000 \\
\hline Experience & 0.006 & 0.005 & 0.206 & 0.012 & 0.006 & 0.053 \\
\hline Serial entrepreneur & 0.041 & 0.097 & 0.678 & -0.018 & 0.146 & 0.904 \\
\hline \multicolumn{7}{|l|}{ Founding team controls } \\
\hline Gender diversity & 1.276 & 0.418 & 0.002 & 1.680 & 0.381 & 0.000 \\
\hline Cultural diversity & -1.736 & 0.498 & 0.000 & -2.278 & 0.714 & 0.001 \\
\hline Citizenship share & 0.334 & 0.340 & 0.326 & 0.743 & 0.477 & 0.119 \\
\hline \multicolumn{7}{|l|}{ Firm level controls } \\
\hline Owner hour share & 0.028 & 0.006 & 0.000 & 0.042 & 0.003 & 0.000 \\
\hline Intellectual property & 0.345 & 0.131 & 0.008 & 0.404 & 0.151 & 0.007 \\
\hline Investment & -0.018 & 0.012 & 0.144 & 0.022 & 0.015 & 0.155 \\
\hline Home-based business & -0.682 & 0.237 & 0.004 & -1.194 & 0.150 & 0.000 \\
\hline \multicolumn{7}{|l|}{ Market controls } \\
\hline Regional market & 0.214 & 0.355 & 0.548 & 0.347 & 0.384 & 0.367 \\
\hline National market & 0.345 & 0.219 & 0.116 & 0.459 & 0.262 & 0.080 \\
\hline International market & -0.030 & 0.250 & 0.906 & -0.264 & 0.331 & 0.425 \\
\hline \multicolumn{7}{|l|}{ Semi-elasticities } \\
\hline Sales: baseline & 0.039 & 0.023 & 0.090 & 0.049 & 0.014 & 0.001 \\
\hline Sales: product-focus & & & & 0.280 & 0.119 & 0.019 \\
\hline Sales: service-focus & & & & 0.067 & 0.029 & 0.019 \\
\hline
\end{tabular}


Table 3 (continued)

\begin{tabular}{|c|c|c|c|c|c|c|}
\hline \multirow[b]{2}{*}{ Lagged DV } & \multicolumn{3}{|l|}{ (1) } & \multicolumn{3}{|l|}{$(2)$} \\
\hline & Coef & SE & $p$ & Coef & SE & $p$ \\
\hline Production: baseline & 0.036 & 0.018 & 0.052 & 0.070 & 0.040 & 0.083 \\
\hline Production: product-focus & & & & 0.048 & 0.017 & 0.006 \\
\hline Production: service-focus & & & & 0.010 & 0.026 & 0.701 \\
\hline R\&D: baseline & -0.025 & 0.036 & 0.494 & -0.065 & 0.050 & 0.195 \\
\hline R\&D: product-focus & & & & 0.007 & 0.074 & 0.929 \\
\hline R\&D: service-focus & & & & -0.008 & 0.036 & 0.817 \\
\hline Owner management: baseline & -0.021 & 0.187 & 0.910 & 0.226 & 0.270 & 0.403 \\
\hline Owner management: product-focus & & & & 0.340 & 0.365 & 0.351 \\
\hline Owner management: service-focus & & & & 0.083 & 0.208 & 0.689 \\
\hline Non-owner management: baseline & -0.036 & 0.019 & 0.054 & 0.049 & 0.050 & 0.320 \\
\hline Non-owner management: product-focus & & & & -0.135 & 0.116 & 0.247 \\
\hline Non-owner management: service-focus & & & & -0.038 & 0.017 & 0.026 \\
\hline \multicolumn{7}{|l|}{ Joint tests of significance } \\
\hline$p$ (Sales marginal effect) & & & & 0.000 & & \\
\hline$p$ (Production marginal effect) & & & & 0.019 & & \\
\hline$p(\mathrm{R} \& \mathrm{D}$ marginal effect $)$ & & & & 0.632 & & \\
\hline$p($ Owner management marginal effect $)$ & & & & 0.742 & & \\
\hline$p$ (Non-owner management marginal effect) & & & & 0.061 & & \\
\hline \multicolumn{7}{|l|}{ Model statistics } \\
\hline Observations & 11,802 & & & 11,802 & & \\
\hline Startup firms & 2484 & & & 2484 & & \\
\hline$p$ (Hansen difference) & 0.440 & & & 0.097 & & \\
\hline$p(\mathrm{AR} 1)$ & 0.004 & & & 0.000 & & \\
\hline$p(\mathrm{AR} 2)$ & 0.669 & & & 0.391 & & \\
\hline Lag limit A & 3 & & & 1 & & \\
\hline Lag limit B & 4 & & & 7 & & \\
\hline No. instruments & 124 & & & 183 & & \\
\hline
\end{tabular}

Notes. System GMM estimates of startup hiring decision effects on firm performance. DV is annual firm revenue, transformed using inverse hyperbolic sine transformation (IHS). IVs include: sales employment, production employment, R\&D employment, and owner and non-owner management employment-all lagged one year relative to DV. Model 1 is baseline. Model 2 includes interactions between IVs and both product and service-focus dummy variables. All models control for: 2 lags of DV; sets of entrepreneur-level, founding team, and firm-level control variables; target market dummy variables; and state, industry and year effects. Standard errors robust to heteroskedasticity and autocorrelation. We use forward orthogonal-deviations in lieu of lagged differences to account for the unbalanced nature of our panel dataset (Arellano \& Bover, 1995). Semi-elasticities computed by applying hyperbolic sine transformation to coefficient estimates and multiplying by X/Y (Bellemare \& Wichman, 2020). Joint tests of significant correspond to joint test of significance of a given IV and its interaction terms (Brambor et al., 2006). $p$ (Hansen difference) denotes the $p$ value from the difference-in-Hansen test for the validity of the SGMM-style instruments. $p$ (AR1) and $p$ (AR2) represent the $p$ values from 1 st and 2nd autocorrelation tests. Instrumental variable matrix collapsed and lag limit AIB imposed to reduce instrument count and minimize instrument proliferation issue (Roodman, 2009b). Reported semi-elasticities are multiplied by 100 for interpretation in the reporting of results in Sect. 5.

impose instrumental variable lag limits that satisfy the following conditions: (i) the null of the difference-in-Hansen over-identification test for the validity of the instruments is not rejected and is not implausibly perfect (i.e., $0.05 \leq p$ (DiffHansen $)<$
1.00); and (ii) there is no second-order autocorrelation (i.e., $p(A R 2)>0.05)$ (Roodman, 2009a, b). We treat the remaining firm-level control variables, and fixed industry, fixed state and period effects as pre-determined. 


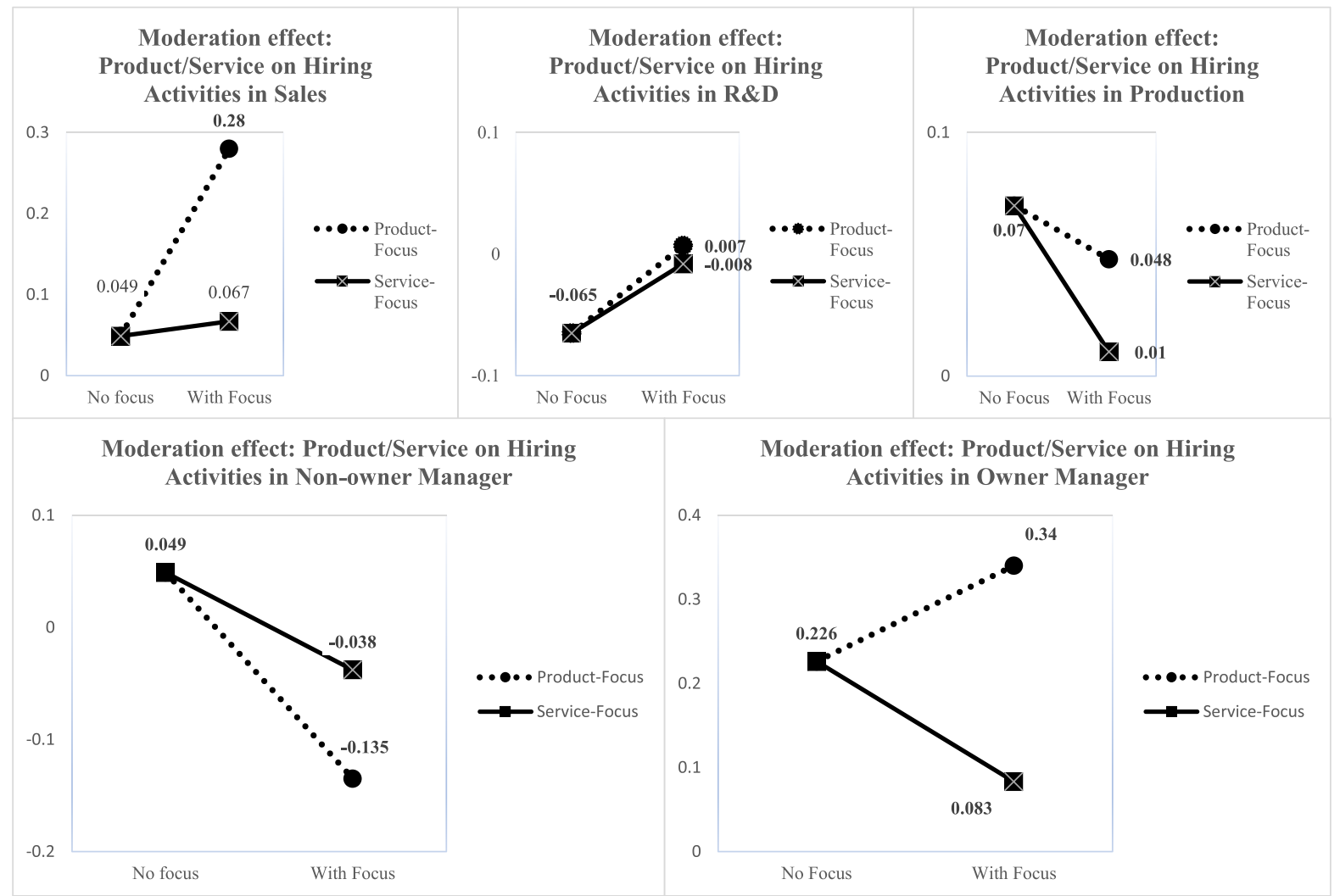

Fig. 3 Moderation effect graphs

\section{Results}

\subsection{Main results}

We present our baseline SGMM results in model 1 of Table $3^{6}$. Consistent with $\mathrm{H} 1$, we find a positive relationship between sales employment and firm performance. The derived semi-elasticity from the coefficient estimate is $3.91 \%\left(p=0.09 ; c i=\left[\begin{array}{ll}0.00 & 0.07\end{array}\right]\right)$, suggesting that a nascent venture which hires an additional sales employee achieves a 3.91 percentage increase in revenue, ceteris paribus. We also observe, consistent with $\mathrm{H} 2$, a positive relationship between production employees and performance. The derived semi-elasticity from the coefficient estimate is $3.57 \%$ $\left(p=0.05 ; c i=\left[\begin{array}{ll}0.00 & 0.06\end{array}\right)\right.$, suggesting that a nascent venture which hires an additional production

\footnotetext{
${ }^{6}$ Reported semi-elasticities are multiplied by 100 for interpretation in the reporting of results in section 5 .
}

employee achieves, all else equal, a 3.57 percentage increase in revenues. Meanwhile, we observe a negative relationship between $\mathrm{R} \& \mathrm{D}$ and firm performance; however, the variable is not statistically significant at the $10 \%$ level. This suggests that the coefficient estimates, and implied semi-elasticities, are not statistically different from zero. The result, which is inconsistent with $\mathrm{H} 3$, implies that adding R\&D personnel does not impact nascent venture performance.

We investigated the role of adding management capacity by decomposing the number of total managers to separately account for the performance effects of owner-managers and non-owner managers, allowing us to test $\mathrm{H} 4 \mathrm{a}$ and $\mathrm{H} 4 \mathrm{~b}$. We include both variables in the same regression and report these results as model 1 in Table 3. We observe, consistent with $\mathrm{H} 4 \mathrm{a}$, that non-owner managers are negatively associated with firm performance. The semi-elasticity is $-3.61 \%$ $(p=0.05 ; \mathrm{c}=[-0.07-0.01])$, suggesting that a nascent venture which hires an additional non-owner manager achieves a 3.61 percentage decrease in revenue, 
ceteris paribus. Meanwhile, the owner-manager variable enters the model negatively, but it is not statistically significant. This result, which is inconsistent with $\mathrm{H} 4 \mathrm{~b}$, suggests that adding owner-managers does not influence nascent venture performance.

\subsection{Moderation results}

Next, we add interaction terms between each of our employment variables and both product-focus and service-focus to test our moderation hypotheses. The baseline omitted category is generalist ventures that offer both products and services. The main effect estimates for each of the employment variables capture the effects of the employee hiring decisions on firm performance for the baseline sample of generalist ventures (see Fig. 3). The effects of employee hiring decisions for product and service-focused firms are captured by the sum of the main effect and respective moderation effect terms (Brambor et al., 2006). We present these results in model 2 of Table 3 and provide graphs of the interaction effects in Fig. 3. In this specification, the $p$ values from joint tests of significance suggest that the marginal effects of sales $(p=0.00)$, production $(p=0.02)$, and non-owner management employment $(p=0.06)$ are statistically significant at conventionally accepted levels, while the joint tests of significance for R\&D employment $(p=0.55)$ and owner-management $(p=0.74)$ are not. As such, we focus our discussion of these results on sales, production, and non-owner management employees, noting that our findings do not provide support for $\mathrm{H} 5 \mathrm{c}$ and $\mathrm{H} 5 \mathrm{e}$.

The baseline semi-elasticity estimate for sales employment is $4.92 \%$ ( $p=0.00 ; c i=\left[\begin{array}{ll}0.03 & 0.07\end{array}\right]$, while the elasticities for product-focused and servicefocused startups are $2.80 \%\left(p=0.02 ; c i=\left[\begin{array}{lll}0.08 & 0.48\end{array}\right]\right)$ and $6.74 \%(p=0.02 ; c i=[0.020 .11])$. These results suggest that hiring sales employees is associated with a performance boost for generalist nascent ventures, but the performance boost is stronger for firms with product and service specialization. These findings provide further support for $\mathrm{H} 1$ and are consistent with H5a. For production employment, the baseline semi-elasticity estimate is $6.96 \%(p=0.08$; $c i=\left[\begin{array}{ll}0.00 & 0.14\end{array}\right]$ ), while the elasticity for productfocused and service-focused ventures are $4.79 \%$ $\left(p=0.02 ; c i=\left[\begin{array}{ll}0.02 & 0.08\end{array}\right]\right)$ and $1.02 \% \quad(p=0.70$; $c i=[-0.03-0.05])$. These findings imply that hiring production employees is associated with an increase in performance for the generalist nascent ventures, but the performance boost is weaker for firms with product and service specialization.

For non-owner management employees, interestingly, we observe that adding non-owner managers is associated with a performance boost for generalist nascent ventures. The baseline semi-elasticity for is $4.93 \%(p=0.32 ; c i=[-0.030 .13])$, which suggests that a generalist firm that hires an additional manager achieves a 4.93 percentage point revenue increase. However, the effect is substantially negatively moderated for specialist firms. For product and service specialist firms, the semi-elasticities are $-13.5 \%$ and $-3.8 \%$, implying that hiring an additional non-owner manager is associated with $\mathrm{a}-13.5$ and -3.8 percentage change in revenue, respectively. These results are inconsistent with $\mathrm{H} 4 \mathrm{a}$, and while firm specialization negatively moderates the relationship between nonowner managers and performance, as suggested by $\mathrm{H} 5 \mathrm{~d}$, the baseline effect is positive such that $\mathrm{H} 5 \mathrm{~d}$ is not supported.

While we are primarily interested in the effects of nascent venture hiring decisions on firm performance, several findings with respect to our control variables are worth mentioning. First, we observe a negative relationship between founding team cultural diversity and performance. While some previous research has found a positive empirical relationship between cultural diversity and firm performance (e.g., Miller \& Del Carmen Triana, 2009), our finding of a negative relationship aligns with threat-rigidity theory, which suggests that cultural diversity may impede changes needed to boost performance (Triana et al., 2013). Second, nascent ventures whose primary owner works more hours, perform better, suggesting that entrepreneurial sweat equity is positively associated with nascent venture performance (Thakur, 1999). Third, we observe that home-based nascent ventures perform worse, a finding that may reflect the motivations of lifestyle entrepreneurs (Walker \& Brown, 2004). Lastly, we do not find any evidence that nascent ventures marketing their products nationally or internationally perform any better than those with a regional focus. For models 1 and 2, the $p$ values of the $\operatorname{AR}(2)$ test are 0.669 and 0.391 , indicating the second-order autocorrelation is not present, and the $p$ values from the difference-in-Hansen test are 0.440 
and 0.097, suggesting that instrumental variables are valid.

\subsection{Additional results}

We re-estimate our main results for the sub-sample of firms with zero employees in the initial year of the survey in order to rule out the possibility that our results are being influenced by firms that experienced some growth, as reflected by having already hired employees, prior to data collection. We present these results, which are similar to our main results, in Appendix Table 5.

As we noted in Sec. 4.6, there is some attrition in the KFS dataset attributable to non-survival, which induces a form of sample selection bias, particularly in understanding long-term venture performance (Gimmon and Levie (2020). While management researchers often employ Heckman two-step methods to deal with sample selection bias, Certo et al. (2016) show using simulations that the bias arising from other sources of endogeneity such as simultaneity, which is typically present in dynamic panel models (Li et al., 2021), is a more serious concern than sample selection bias when both forms of endogeneity are present. In such instances, Certo et al. (2016) suggest that researchers use instrumental variable methods (e.g., SGMM) to deal with the endogeneity created by simultaneity, but also to compare the results to a Heckman two-step model. Although standard Heckman models do not deal with the endogeneity present in dynamic panel data models ( $\mathrm{Li}$ et al., 2021), we nonetheless performed an ad-hoc two-step method as a means to attempt to control for selection effects and compare the results to our SGMM estimates.

First, we estimate a fixed-effects logit model using firm survival (dummy $=1$ if firm continues in dataset in year $t$ ) as the DV. We then computed the Inverse Mills Ratio (IMR) using the estimates from this regression. Finally, we include the IMR as a control variable in our SGMM model. Because brand new ventures exhibit a liability of newness, while businesses that previously existed and franchises have some legitimacy, it is conceivable theoretically that the rates of survival are lower among the former than the latter. As such, we include several variables reflecting how the firm was started in the Logit but not the SGMM estimates as a means to satisfy the exclusion restriction (Bascle, 2008; Certo et al.,
2016). The results, which we present in Appendix Table 4, indicate that sample selection is not a major concern as IMR is not statistically significant in the SGMM model. Interestingly, we observe in the firststep Logit estimates that none of the employment variables are associated with survival, suggesting that firm hiring decisions do not have any effect on firm survival. Meanwhile, the estimates in the second-step SGMM estimates for our employment variables are very similar to our main results.

\section{Discussion}

In this study, we developed a theoretical framework and empirically tested hypotheses that delineate the impact of entrepreneurial organizing activities on nascent venture performance. Specifically, we model the performance effects of adding boundary span (i.e., sales), technical core (i.e., production and R\&D), and management capacity, as manifested by the hiring of staff to these respective areas. Adding capacity to these areas represents entrepreneurs' judgments about how to best allocate scarce resources (Foss et al., 2019; Gartner \& Starr, 1993; Katz \& Gartner, 1988). We add that resource limitation means entrepreneurs cannot typically engage in multiple organizing activities, such as hiring staff in multiple units concurrently. In that vein, our study revealed that while not all new ventures hire in the early years, of those that do, more than $90 \%$ add staff to one of the areas we delineate. This suggests that hiring staff in nascent ventures is a strategic trade-off decision where one area of the firm is emphasized over others.

Consistent with our hypothesis, our findings from SGMM estimation for a sample of 2484 nascent ventures suggest that adding boundary span and technical core capacity boosts firm performance, and mixed impact on performance from adding management under certain conditions. More specifically, we found a positive impact on firm performance from hiring sales and production unit employees, but a negative impact on firm performance from hiring non-owner management employees. Further, we found that specialized nascent ventures (i.e., offer only products or services, but not both) receive a performance boost, relative to generalist firms, from boundary-spanning activities (i.e., hiring sales employees). These findings are insightful, because though specialization 
versus generalization has long been cited as a factor in well-established and typically large organizations, we document it an as a key element in the organizing of nascent ventures (i.e., entrepreneurial organizing).

This is best illustrated by the intriguing and, potentially, counterintuitive finding of a moderating effect from specialization on the relationship between adding management capacity and performance. Although we observed a negative direct effect (in the sample with a mixture of generalized and specialized firms) on performance from adding non-owner management capacity, we found a more complex outcome when we separated the generalized and specialized firms. Particularly, we found that adding non-owner management capacity penalized firm performance when the nascent venture has a specialized productfocused model. However, for the nascent venture with a generalized model, adding non-owner management capacity increased firm performance. Because existing organization theory literature reports that small firms tend to adopt a specialization model while large more mature firms tend to use a generalization model (Dobrev et al., 2001; Freeman \& Hannan, 1983), it suggested that hiring into management department can be more complex and dynamic in terms of allocating resources to hiring owner-management and non-owner management in these firms.

\subsection{Theoretical contributions}

Our study has important implications for the entrepreneurial organizing literature. First, we demonstrate that Thompson's (1967) well-established action perspective, which has traditionally been deployed to explain organizing activities in large established organizations, can also be applied to provide a new way of delineating entrepreneurial organizing activities (i.e., boundary span, technical core, and management). While entrepreneurship scholars widely recognize that entrepreneurs organize under conditions of uncertainty (Baker \& Nelson, 2005; Brush et al., 2001; Huang \& Knight, 2017), the framework has paid less attention to resource constraint assumptions. We address this by infusing organizing activities with a "trade-off" logic. Specifically, when an entrepreneur decides to allocate scarce resources, including their own time and effort, to engage in particular organizing activity, s/he implicitly does so at the expense of resource investments in alternative activities. This necessitates, given resource constraints, that entrepreneurs hold steady, or even reduce, commitments to other areas. We provide, therefore, a new lens to unpack entrepreneurial organizing as a trade-off decision that reveals what areas of nascent ventures are emphasized and how doing so differentially affects venture performance.

Second, we contribute to the entrepreneurial organizing literature by extending understanding beyond the pre-venture formation stage to introduce a complementary theoretical framework that models organizing in the post-founding stage. In the early years of a new venture's life, nascent ventures must continue to engage in organizing activities in the pursuit of profits (Foss et al., 2019). This moves past organizing activities as a driver of new venture creation (Delmar \& Shane, 2004; Honig \& Karlsson, 2004; Reynolds \& Curtin, 2007) to understand the relationship between organizing activities and the performance of those ventures that are created. By making this shift, we offer insights from Thompson's (1967) action framework to provide previously missing theoretical links between the specific organizing activities that unfold after venture founding and the effects of those activities on venture performance. Hence, our study adds richness to the current understanding of entrepreneurial organizing activities as part of a broader entrepreneurial journey (McMullen \& Dimov, 2013).

A third theoretical contribution that flows from our study is that we advance existing entrepreneurial organizing literature by bringing to the fore the role of specialization versus generalization as an impactful but previously unexplored factor. Organizational theorists have long studied the topic of specialization and generalization (Dobrev et al., 2001; Freeman \& Hannan, 1983), shedding valuable light on how specialization versus generalization may lead to variation in organizational resource allocations (Carroll et al., 2002), innovation levels (Podolny et al., 1996), and long-term survivability (Dowell \& Swaminathan, 2000). These insights, however, have received limited attention in entrepreneurship studies. Our study connects specialization versus generalization to entrepreneurial organizing by conceptualizing that the same activity (i.e., hiring decisions) may have a differential effect on venture outcomes, depending on whether the nascent venture is a specialist or generalist.

This new understanding may be informative for perspectives such as organizational ecology that 
considers different "species" of firms and partitions them accordingly (Bertoni et al., 2019; McKelvey, 1982). Our findings suggest that a new dividing line in species delineation could be specialization versus generalization and the variation in effects of organizational resource allocations therein. It is this type of application of our model and findings to broader areas of management studies research that holds great potential for the advancement of future theory. Indeed, it is understood that the power of organizations flows from "their ability to construct credible imaginaries and to shape the future through them" (Beckert, 2021, p. 3). Yet, there is still much to be learned about the specific actions that shape the future and which actions are more likely to generate desired outcomes. Out study reveals that contouring credible imaginaries in nascent ventures rest, in part, on specific resource allocations and by identifying previously hidden optimally in these allocation decisions, we hope that our findings stimulate future research that considers how highlighting some functional areas over other influences performance trajectories as organizations mature.

\subsection{Practical implications}

Our findings also provide important implications for practitioners who are involved in the entrepreneurial process, whether the process takes place in establishing a new business or starting a new project within an established business. While the existing practitioner-based literature encourages entrepreneurs to take action (e.g., Schlesinger \& Kiefer, 2012), we encourage practitioners to understand that when it comes to organizing, their actions focus attention toward key areas of the endeavor. This, in turn, has consequences. Our findings suggest that entrepreneurs should be mindful that organizing to emphasize boundary spanning, for example, can lead to different results than when production or $\mathrm{R} \& \mathrm{D}$ is emphasized via the hiring of new employees in those areas. Entrepreneurs, particularly those with specialization models, might prioritize hiring into units that are "closer" to the customers by allocating resources toward hiring sales staff and/or staff that produces and delivers their product or service. Our findings, however, suggest that entrepreneurs exercise caution before allocating scarce resources to coordinating roles (i.e., hiring non-management staff), as we found that nascent ventures are likely to experience a performance penalty for doing so. These same insights apply to entrepreneurs in a corporate setting. Indeed, the process of stewarding a nascent innovation project in an established firm tends to exhibit the same resource constraints and trade-offs in organizing as nascent venture who are delivering new products/services to the market.

\subsection{Limitations and future research}

As with all empirical research, our study has limitations that create opportunities for future research. First, our findings concerning nascent venture hiring decisions and firm performance should be viewed as short-run effects. The KFS provides longitudinal data for a random sample of nascent ventures, which allows us to examine this linkage over time (McMullen \& Dimov, 2013), but the time coverage is limited to the first 8 years of venture existence. We do not, therefore, have enough data to examine the stability of our findings as long-term performance effects of hiring decisions during the nascent venture stage. It is possible that when examined over longer time horizons, some observed effects may diverge from the short-run effects we document here. An area of keen interest for future research would then be to explore how organizing via staff hiring decisions impacts performance over the long term and the degree to which there is an imprinting effect (Mathias et al., 2015). Furthermore, Gimmon and Levie's (2020) recent exploration of very long-term venture performance finds that the imprinting of early sales traction is an indicator of product-market fit and, therein, leads to higher long-term performance. Since our study is focused on the early stages, we encourage future research that builds on our findings and links them to those of Gimmon and Levie (2020) in an effort to further unpack the relationship between early stage organizing decisions, such as staff hiring, and longerterm venture outcomes.

Second, we provide some evidence that the performance effects of hiring decisions for specialized firms differ from generalist firms. Our proxies for specialization are limited to whether a venture has a product or service focus. As such, our data does not capture information about a firm-level product and/or service diversification. It is conceivable, for instance, that a venture with a product-focus that we classify 
as specialized offers a diverse product mix and may, therefore, affect venture performance differently. Because the firms in our sample are nascent ventures, they typically lack the size and resources for a diverse within-category mix (i.e., multiple product offerings). As such, we are confident that this concern does not have a significant effect on our approach. That said, future research that takes a more granular approach to specialization would help us better understand the nuances of the role of specialization in nascent venture organizing.

Third, we provide some evidence that the hiring of non-management employees by nascent ventures is associated with lower performance. However, managers have heterogeneous backgrounds and may serve in different functional roles that differentially influence the growth trajectory of a startup. For instance, a sales manager is more likely to be engaged in boundary spanning activities that contribute to nearterm venture growth than an administrative manager. Given limitations in the KFS dataset, we are unable to further delineate the functions and/or backgrounds of management employees to ascertain how such factors may differentially influence nascent venture performance, but better understanding this heterogeneity would be a valuable future research endeavor.

Finally, we use employee hiring decisions to capture nascent venture organizing activities. Such activities may materialize in ways other than employment decisions. Entrepreneurs must also make judgments on how to invest scarce resources in different types of capital and other firm capabilities (Foss et al., 2019). While there is likely a correlation between labor and non-labor investments in nascent ventures, future research that explores alternative aspects of organizing activities could provide additional insights on the link between nascent venture organization activities and firm performance. Additionally, due to the nature of the KFS dataset, our analysis pertains to entrepreneurial organizing activities that take place after a firm's founder(s) took formal steps to launch the venture. It does not, therefore, illuminate how entrepreneurial organizing activities, including staffing decisions, prior to formal creation of their ventures influence firm performance. Additional research is needed to examine how entrepreneurs' pre-formalization organizing activities influence nascent venture performance, including venture continuation and formalization.

\section{Conclusion}

At the outset of this study, we aimed to understand entrepreneurial organizing activities beyond the preventure creation stage by exploring how hiring activities, as a key element of organizing, impact the trajectory of nascent venture performance. To do this we brought forward an action framework and our findings demonstrate its utility as a theoretical lens for unpacking the role and influence of specific resources allocation decisions that are emblematic of entrepreneurial organizing as a phenomenon. The net effect is the generation of important theoretical and empirical insights that form a more complete picture of entrepreneurial organizing.

Acknowledgements The authors would like to Phil Kim and Johan Wiklund for valuable comments on an earlier versions of the manuscript. A previous version of this paper was accepted for presentation at the 2020 Babson Entrepreneurship Research Conference.

Funding We are grateful for financial support provided by the Department of Entrepreneurship at Baylor University.

Open Access This article is licensed under a Creative Commons Attribution 4.0 International License, which permits use, sharing, adaptation, distribution and reproduction in any medium or format, as long as you give appropriate credit to the original author(s) and the source, provide a link to the Creative Commons licence, and indicate if changes were made. The images or other third party material in this article are included in the article's Creative Commons licence, unless indicated otherwise in a credit line to the material. If material is not included in the article's Creative Commons licence and your intended use is not permitted by statutory regulation or exceeds the permitted use, you will need to obtain permission directly from the copyright holder. To view a copy of this licence, visit http://creativecommons.org/licenses/by/4.0/.

\section{References}

Alam, I. (2002). An exploratory investigation of user involvement in new service development. Journal of the Academy of Marketing Science, 30(3), 250-261. https://doi. org/10.1177/0092070302303006

Aldrich, H. (1999). Organizations evolving ((2nd ed) ed.). SAGE.

Aldrich, H., \& Herker, D. (1977). Boundary spanning roles and organization structure. Academy of Management Review, 2(2), 217-230. https://doi.org/10.2307/257905

Aldrich, H., \& Yang, T. (2014). How do entrepreneurs know what to do? Learning and organizing in new ventures. 
Journal of Evolutionary Economics, 24(1), 59-82. https://doi.org/10.1007/s00191-013-0320-x

Allen, T. J. (1977). Managing the flow of technology: Technology transfer and the dissemination of technological information within the $R \& D$ organisation. The Massachusetts Institute of Technology.

Alvarez, S. A., \& Barney, J. B. (2007). Discovery and creation: Alternative theories of entrepreneurial action. Strategic Entrepreneurship Journal, 1(1-2), 11-26. https://doi.org/ $10.1002 /$ sej. 4

Amabile, T. M. (1996). Creativity and innovation in organizations.

Ambrosini, V., \& Bowman, C. (2001). Tacit knowledge: Some suggestions for operationalization. Journal of Management Studies, 38(6), 811-829. https://doi.org/10.1111/ 1467-6486.00260

Arellano, M., \& Bover, O. (1995). Another look at the instrumental variable estimation of error-components models. Journal of Econometrics, 68(1), 29-51. https://doi.org/ 10.1016/0304-4076(94)01642-D

Argote, L., \& Miron-Spektor, E. (2011). Organizational learning: From experience to knowledge. Organization Science, 22(5), 1123-1137. https://doi.org/10.1287/orsc. 1100.0621

Arrow, K. J. (1984). The economics of agency. In Institute for Mathematical Studies in the Social Sciences. Stanford University.

Audretsch, D. B., Lehmann, E. E., \& Plummer, L. A. (2009). Agency and governance in strategic entrepreneurship. Entrepreneurship Theory and Practice, 33(1), 149-166. https://doi.org/10.1111/j.1540-6520.2008.00284.x

Avlonitis, G. J., Papastathopoulou, P. G., \& Gounaris, S. P. (2001). An empirically-based typology of product innovativeness for new financial services: Success and failure scenarios. Journal of Product Innovation Management, 18(5), 324-342. https://doi.org/10.1111/1540-5885. 1850324

Baker, T., \& Nelson, R. E. (2005). Creating something from nothing: Resource construction through entrepreneurial bricolage. Administrative Science Quarterly, 50(3), 329366. https://doi.org/10.2189/asqu.2005.50.3.329

Bascle, G. (2008). Controlling for endogeneity with instrumental variables in strategic management research. Strategic Organization, 6(3), 285-327. https://doi.org/10.1177/ 1476127008094339

Becker, S. W., \& Gordon, G. (1966). An entrepreneurial theory of formal organizations part I: Patterns of formal organizations. Administrative Science Quarterly, 315-344.

Beckert, J. (2021). The firm as an engine of imagination: Organizational prospection and the making of economic futures. Organization Theory. https://doi.org/10.1177/ 26317877211005773

Bellemare, M. F., \& Wichman, C. J. (2020). Elasticities and the inverse hyperbolic sine transformation. Oxford Bulletin of Economics and Statistics, 82(1), 50-61. https://doi. org/10.1111/obes.12325

Bennett, D. (2019a). Local economic freedom and creative destruction in America. Small Business Economics, 1-21. https://doi.org/10.1007/s11187-019-00222-0

Bennett, D. (2019b). Infrastructure investments and entrepreneurial dynamism in the U.S. Journal of Business
Venturing, 34(5), 105907. https://doi.org/10.1016/j.jbusv ent.2018.10.005

Bertoni, F., Colombo, M. G., \& Quas, A. (2019). The role of governmental venture capital in the venture capital ecosystem: An organizational ecology perspective. Entrepreneurship Theory and Practice, 43(3), 611-628. https:// doi.org/10.1177/1042258717735303

Birley, S. (1984). Finding the new firm. In In Academy of management proceedings (1984th ed., pp. 64-68). Academy of Management Briarcliff Manor.

Blau, P. M. (1977). Inequality and heterogeneity: A primitive theory of social structure. Free Press.

Blundell, R., \& Bond, S. (1998). Initial conditions and moment restrictions in dynamic panel data models. Journal of Econometrics, 87(1), 115-143. https://doi.org/10.1016/ S0304-4076(98)00009-8

Bonaccorsi, A., \& Rossi, C. (2003). Why Open Source software can succeed. Research Policy, 32(7), 1243-1258. https://doi.org/10.1016/S0048-7333(03)00051-9

Boyer, T., \& Blazy, R. (2014). Born to be alive? The survival of innovative and non-innovative French micro-start-ups. Small Business Economics, 42(4), 669-683. https://doi. org/10.1007/s11187-013-9522-8

Brambor, T., Clark, W. R., \& Golder, M. (2006). Understanding interaction models: Improving empirical analyses. Political analysis, 14(1), 63-82.

Brentani, U. D. (1991). Success factors in developing new business services. Text, Emerald Group Publishing Limited. https://doi.org/10.1108/03090569110138202

Brinckmann, J., Grichnik, D., \& Kapsa, D. (2010). Should entrepreneurs plan or just storm the castle? A meta-analysis on contextual factors impacting the business planning-performance relationship in small firms. Journal of Business Venturing, 25(1), 24-40. https://doi.org/10. 1016/j.jbusvent.2008.10.007

Brush, C. G., Greene, P. G., \& Hart, M. M. (2001). From initial idea to unique advantage: The entrepreneurial challenge of constructing a resource base. Academy of Management Perspectives, 15(1), 64-78. https://doi.org/10.5465/ame. 2001.4251394

Brush, C. G., Manolova, T. S., \& Edelman, L. F. (2008). Properties of emerging organizations: An empirical test. Journal of Business Venturing, 23(5), 547-566. https://doi. org/10.1016/j.jbusvent.2007.09.002

Burns, T., \& Stalker, G. M. (1961). The management of innovation. London. Tavistock Publishing. Cited in Hurley, RF and Hult, GTM (1998). Innovation, market orientation, and organisational learning: An integration and empirical examination. Journal of Marketing, 62, 42-54.

Cader, H., \& Leatherman, J. (2011). Small business survival and sample selection bias. Small Business Economics, 37(2), 155-165. https://doi.org/10.1007/ s11187-009-9240-4

Campbell, B. A., Ganco, M., Franco, A. M., \& Agarwal, R. (2012). Who leaves, where to, and why worry? Employee mobility, entrepreneurship and effects on source firm performance. Strategic Management Journal, 33(1), 65-87. https://doi.org/10.1002/smj.943

Carroll, G. R., Dobrev, S. D., \& Swaminathan, A. (2002). Organizational processes of resource partitioning. 
Research in Organizational Behavior, 24, 1-40. https:// doi.org/10.1016/S0191-3085(02)24002-2

Carter, N. M., Gartner, W. B., \& Reynolds, P. D. (1996). Exploring start-up event sequences. Journal of Business Venturing, 11(3), 151-166.

Certo, S. T., Busenbark, J. R., Woo, H.-S., \& Semadeni, M. (2016). Sample selection bias and Heckman models in strategic management research. Strategic Management Journal, 37(13), 2639-2657. https://doi.org/10.1002/smj. 2475

Claussen, J., Essling, C., \& Peukert, C. (2018). Demand variation, strategic flexibility and market entry: Evidence from the U.S. airline industry. Strategic Management Journal, 39(11), 2877-2898. https://doi.org/10.1002/smj.2940

Cohen, W. M., \& Levinthal, D. A. (1994). Fortune favors the prepared firm. Management Science, 40(2), 227-251. https://doi.org/10.1287/mnsc.40.2.227

Courpasson, D., Dany, F., \& Martí, I. (2016). Organizational entrepreneurship as active resistance: A struggle against outsourcing. Entrepreneurship Theory and Practice, 40(1), 131-160. https://doi.org/10.1111/etap.12109

Croce, A., Marti, J., \& Murtinu, S. (2013). The impact of venture capital on the productivity growth of European entrepreneurial firms: "Screening" or "value added" effect? Journal of Business Venturing, 28(4), 489. https:// doi.org/10.1016/j.jbusvent.2012.06.001

Daft, R. L. (1998). Organization theory. Design, South-Western College Publishing.

Delmar, F., \& Shane, S. (2004). Legitimating first: Organizing activities and the survival of new ventures. Journal of Business Venturing, 19(3), 385-410. https://doi.org/10. 1016/S0883-9026(03)00037-5

Dencker, J. C., \& Gruber, M. (2015). The effects of opportunities and founder experience on new firm performance. Strategic Management Journal, 36(7), 1035. https://doi. org/10.1002/smj.2269

Dess, G. G., \& Beard, D. W. (1984). Dimensions of organizational task environments. Administrative Science Quarterly, 29(1), 52-73. https://doi.org/10.2307/2393080

Dobrev, S. D., Kim, T.-Y., \& Carroll, G. R. (2002). The evolution of organizational niches: US automobile manufacturers, 1885-1981. Administrative Science Quarterly, 47(2), 233-264. https://doi.org/10.2307/3094805

Dobrev, S., Tai-Young, K., \& Hannan, M. (2001). Dynamics of niche width and resource partitioning. The American Journal of Sociology, 106(5), 1299-1337. https://doi.org/ $10.1086 / 320821$

Dosi, G., Pugliese, E., \& Santoleri, P. (2017). Growth and survival of the "fitter"? Evidence from US new-born firms https://www.econstor.eu/handle/10419/174556

Dowell, G., \& Swaminathan, A. (2000). Racing and backpedalling into the future: New product introduction and organizational mortality in the US bicycle industry, 1880-1918. Organization Studies, 21(2), 405-431. https://doi.org/10.1177/0170840600212005

Eisenhardt, K. M., \& Schoonhoven, C. B. (1990). Organizational growth: Linking founding team, strategy, environment, and growth among US semiconductor ventures, 1978-1988. Administrative Science Quarterly, 1990, 504-529. https://doi.org/10.2307/2393315
El Sawy, O. A., Malhotra, A., Park, Y., \& Pavlou, P. A. (2016). Research commentary-Seeking the configurations of digital ecodynamics: It takes three to tango. Information Systems Research, 21(4), 835-848. https://doi.org/10. 1287/isre.1100.0326

Farhat, J., Matusik, S., Robb, A., \& Robinson, D. T. (2018). New directions in entrepreneurship research with the Kauffman Firm Survey. Small Business Economics, 50(3), 521-532. https://doi.org/10.1007/ s11187-017-9905-3

Farhat, J. B., \& Robb, A. (2014). Applied survey data analysis using Stata. The Kauffman firm survey data Available at SSRN 2477217.

Farhat, J., \& Robb, A. (2018). Analyzing complex survey data: the Kauffman firm survey. Small Business Economics, 50(3), 657-670. https://doi.org/10.1007/ s11187-017-9913-3

Foss, N. J., Klein, P. G., \& Bjørnskov, C. (2019). The context of entrepreneurial judgment: Organizations, markets, and institutions. Journal of Management Studies, 56(6), 1197-1213. https://doi.org/10.1111/joms.12428

Freeman, J., \& Hannan, M. T. (1983). Niche width and the dynamics of organizational populations. American Journal of Sociology, 88(6), 1116-1145.

Friedman, R., \& Podolny, J. (1992). Differentiation of boundary spanning roles: Labor negotiations and implications for role conflict. Administrative Science Quarterly, 37(1), 28-47. https://doi.org/10.2307/2393532

Garonne, C., \& Davidsson, P. (2010). Do strategy choices matter for nascent firms? Effectuation in the early stages of venture creation.

Gartner, W. B., Carter, N. M., \& Reynolds, P. D. (2010). Entrepreneurial behavior: Firm organizing processes. In Handbook of entrepreneurship research (pp. 99-127). Springer.

Gartner, W. B., \& Starr, J. (1993). The nature of entrepreneurial work. Entrepreneurship Research: Global perspectives.

Gatewood, E. J., Shaver, K. G., \& Gartner, W. B. (1995). A longitudinal study of cognitive factors influencing startup behaviors and success at venture creation. Journal of Business Venturing, 10(5), 371-391. https://doi.org/10. 1016/0883-9026(95)00035-7

Gimmon, E., \& Levie, J. (2020). Early indicators of very long term venture performance: A 20 year panel study. Academy of Management Discoveries, (In press). https://doi. org/10.5465/amd.2019.0056

Grabowski, H. G., \& Vernon, J. M. (1994). Returns to R\&D on new drug introductions in the 1980s. Journal of Health Economics, 13(4), 383-406. https://doi.org/10.1016/ 0167-6296(94)90010-8

Grichnik, D., Brinckmann, J., Singh, L., \& Manigart, S. (2014). Beyond environmental scarcity: Human and social capital as driving forces of bootstrapping activities. Journal of Business Venturing, 29(2), 310-326. https://doi.org/ 10.1016/j.jbusvent.2013.02.006

Grimpe, C., Murmann, M., \& Sofka, W. (2019). Organizational design choices of high-tech startups: How middle management drives innovation performance. Strategic Entrepreneurship Journal, 13(3), 359-378. https://doi.org/10. 1002/sej.1330 
Gruber, M. (2007). Uncovering the value of planning in new venture creation: A process and contingency perspective. Journal of Business Venturing, 22(6), 782-807. https:// doi.org/10.1016/j.jbusvent.2006.07.001

Gruber, M., MacMillan, I. C., \& Thompson, J. D. (2008). Look before you leap: Market opportunity identification in emerging technology firms. Management Science, 54(9), 1652-1665. https://doi.org/10.1287/mnsc.1080.0877

Hamilton, B. H., \& Nickerson, J. A. (2003). Correcting for endogeneity in strategic management research. Strategic Organization, 1(1), 51-78. https://doi.org/10.1177/14761 27003001001218

Hannan, M. T., \& Freeman, J. (1989). Organizational ecology. Harvard university press.

Hayek, F. A. (1945). The use of knowledge in society. The American Economic Review, 35(4), 519-530.

Heckman, J. J. (1976). The common structure of statistical models of truncation, sample selection and limited dependent variables and a simple estimator for such models. In In Annals of economic and social measurement (5 4 ed., pp. 475-492). NBER.

Heckman, J. (1979). Sample selection bias as a specification error (with an application to the estimation of labor supply functions). NBER Working Paper Series, 172. https:// doi.org/10.3386/w0172

Honig, B., \& Karlsson, T. (2004). Institutional forces and the written business plan. Journal of Management, 30(1), 29-48. https://doi.org/10.1016/j.jm.2002.11.002

Huang, L., \& Knight, A. P. (2017). Resources and relationships in entrepreneurship: An exchange theory of the development and effects of the entrepreneur-investor relationship. Academy of Management Review, 42(1), 80-102. https://doi.org/10.5465/amr.2014.0397

Jackson, S., \& Dutton, J. (1988). Discerning threats and opportunities. Administrative Science Quarterly, 33(3), 370370. https://doi.org/10.2307/2392714

Jaruzelski, B., \& Dehoff, K. (2010). How the top innovators keep winning. Strategy. Business, 61.

Jensen, M. C., \& Meckling, W. H. (1977). Between freedom and democracy (pp. 39-49). The Banker.

Jensen, M. C., \& Murphy, K. J. (1990). Performance pay and top-management incentives. Journal of Political Economy, 98(2), 225-264.

Johne, A., \& Storey, C. (1998). New service development: $A$ review of the literature and annotated bibliography. Text, Emerald Group Publishing Limited info: doi/10.1108/03090569810204526.

Katz, J., \& Gartner, W. (1988). Properties of emerging organizations. The Academy of Management Review, 13(3), 429-441. https://doi.org/10.2307/258090

Kaynak, H. (2005). Implementing JIT purchasing: Does the level of technical complexity in the production process make a difference? Journal of Managerial Issues, 17(1), $76-100$.

Kothari, S., Laguerre, T., \& Leone, A. (2002). Capitalization versus expensing: Evidence on the uncertainty of future earnings from capital expenditures versus R\&D outlays. Review of Accounting Studies, 7(4), 355-382. https://doi. org/10.1023/A:1020764227390

Lange, J. E., Mollov, A., Pearlmutter, M., Singh, S., \& Bygrave, W. D. (2007). Pre-start-up formal business plans and post-start-up performance: A study of 116 new ventures. Venture Capital, 9(4), 237-256. https://doi.org/10.1080/ 13691060701414840

Leiponen, A., \& Helfat, C. E. (2010). Innovation objectives, knowledge sources, and the benefits of breadth. Strategic Management Journal, 31(2), 224-236. https://doi.org/10. 1002/smj.807

Li, J., Ding, H., Hu, Y., \& Wan, G. (2021). Dealing with dynamic endogeneity in international business research. Springer.

Li, Y.-H., Huang, J.-W., \& Tsai, M.-T. (2009). Entrepreneurial orientation and firm performance: The role of knowledge creation process. Industrial Marketing Management, 38(4), 440-449. https://doi.org/10.1016/j.indmarman. 2008.02.004

Liao, J., \& Gartner, W. B. (2006). The effects of pre-venture plan timing and perceived environmental uncertainty on the persistence of emerging firms. Small Business Economics, 27(1), 23-40. https://doi.org/10.1007/ s11187-006-0020-0

Liao, J., Welsch, H., \& Tan, W.-L. (2005). Venture gestation paths of nascent entrepreneurs: Exploring the temporal patterns. The Journal of High Technology Management Research, 16(1), 1-22. https://doi.org/10.1016/j.hitech. 2005.06.001

Lichtenstein, B. B., Carter, N. M., Dooley, K. J., \& Gartner, W. B. (2007). Complexity dynamics of nascent entrepreneurship. Journal of Business Venturing, 22(2), 236-261. https://doi.org/10.1016/j.jbusvent.2006.06.001

Lounsbury, M., \& Glynn, M. A. (2001). Cultural entrepreneurship: Stories, legitimacy, and the acquisition of resources. Strategic Management Journal, 22(6-7), 545564. https://doi.org/10.1002/smj.188

Lysonski, S. J., \& Johnson, E. M. (1983). The sales manager as a boundary spanner: A role theory analysis. Journal of Personal Selling \& Sales Management, 3(2), 8-21.

Mann, C. L., \& Sanyal, P. (2010). The financial structure of startup firms. The role of assets, information, and entrepreneur characteristics.

Manolova, T. S., Edelman, L. F., Brush, C. G., \& Rotefoss, B. (2012). Properties of emerging organizations: Empirical evidence from Norway. Small Business Economics, 39(3), 763-781. https://doi.org/10.1007/ s11187-011-9360-5

March, J. G. (1991). Exploration and exploitation in organizational learning. Organization Science, 2(1), 71-87.

Marschak, J., \& Radner, R. (1972). Economic theory of teams. Yale University Press.

Mathias, B. D., Williams, D. W., \& Smith, A. R. (2015). Entrepreneurial inception: The role of imprinting in entrepreneurial action. Journal of Business Venturing, 30(1), 11-28. https://doi.org/10.1016/j.jbusvent.2014.07.004

McGee, J. E., \& Dowling, M. J. (1994). Using R\&D cooperative arrangements to leverage managerial experience: A study of technology-intensive new ventures. Journal of Business Venturing, 9(1), 33-48.

McGee, J. E., Dowling, M. J., \& Megginson, W. L. (1995). Cooperative strategy and new venture performance: The role of business strategy and management experience. Strategic Management Journal, 16(7), 565-580. https:// doi.org/10.1002/smj.4250160706 
McKelvey, B. (1982). Organizational systematics-Taxonomy, evolution, classification. University of California Press.

McMullen, J. S., \& Dimov, D. (2013). Time and the entrepreneurial journey: The problems and promise of studying entrepreneurship as a process. Journal of Management Studies, 50(8), 1481-1512. https://doi.org/10.1111/joms. 12049

McMullen, J. S., \& Shepherd, D. A. (2006). Entrepreneurial action and the role of uncertainty in the theory of the entrepreneur. Academy of Management Review, 31(1), 132-152. https://doi.org/10.5465/amr.2006.19379628

Mehran, H. (1995). Executive compensation structure, ownership, and firm performance. Journal of Financial Economics, 38(2), 163-184.

Metters, R., \& Vargas, V. (2000). A typology of de-coupling strategies in mixed services. Journal of Operations Management, 18(6), 663-682. https://doi.org/10.1016/S02726963(00)00038-3

Michelacci, C. (2003). Low returns in R\&D due to the lack of entrepreneurial skills. The Economic Journal, 113(484), 207-225. https://doi.org/10.1111/1468-0297.00095

Miller, T., \& Del Carmen Triana, M. (2009). Demographic diversity in the boardroom: Mediators of the board diversity-firm performance relationship. Journal of Management Studies, 46(5), 755-786. https://doi.org/10.1111/j. 1467-6486.2009.00839.x

Mishra, D. P., Heide, J. B., \& Cort, S. G. (1998). Information asymmetry and levels of agency relationships. Journal of Marketing Research, 35(3), 277-295. https://doi.org/10. 2307/3152028

Müller, K., \& Peters, B. (2010). Churning of $R \& D$ personnel and innovation (pp. 10-032). ZEW-Centre for European Economic Research Discussion Paper.

Murphy, G. B., Trailer, J. W., \& Hill, R. C. (1996). Measuring performance in entrepreneurship research. Journal of Business Research, 36(1), 15-23. https://doi.org/10. 1016/0148-2963(95)00159-X

Musaji, S., Schulze, W. S., \& De Castro, J. O. (2019). How long does it take to "get to" the learning curve? Academy of Management Journal. https://doi.org/10.5465/amj. 2017.1145

Navis, C., \& Ozbek, O. V. (2016). The right people in the wrong places: The paradox of entrepreneurial entry and successful opportunity realization. Academy of Management Review, 41(1), 109-129. https://doi.org/10.5465/ amr.2013.0175

Nelson, R. R., \& Winter, S. G. (1982). An evolutionary theory of economic change. Belknap Press: An Imprint of Harvard University Press.

Nickell, S. (1981). Biases in dynamic models with fixed effects. Econometrica.

Niebuhr, A. (2006). Migration and innovation: Does cultural diversity matter for regional R\&D activity.

Onyemah, V., Rouziès, D., \& Panagopoulos, N. G. (2010). How HRM control affects boundary-spanning employees' behavioural strategies and satisfaction: the moderating impact of cultural performance orientation. The International Journal of Human Resource Management, 21(11), 1951-1975. https://doi.org/10.1080/09585192. 2010.505096
Pagell, M., Klassen, R., Johnston, D., Shevchenko, A., \& Sharma, S. (2015). Are safety and operational effectiveness contradictory requirements: The roles of routines and relational coordination. Journal of Operations Management, 36(1), 1-14. https://doi.org/10.1016/j.jom. 2015.02.002

Pappas, J. M., \& Wooldridge, B. (2007). Middle managers' divergent strategic activity: An investigation of multiple measures of network centrality. Journal of Management Studies, 44(3), 323-341. https://doi.org/10.1111/j.14676486.2007.00681.x

Park, S., \& Bae, Z.-T. (2004). New venture strategies in a developing country: Identifying a typology and examining growth patterns through case studies. Journal of Business Venturing, 19(1), 81-105. https://doi.org/10. 1016/S0883-9026(02)00110-6

Parker, S. C., \& Belghitar, Y. (2006). What happens to nascent entrepreneurs? An econometric analysis of the PSED. Small Business Economics, 27(1), 81-101. https://doi. org/10.1007/s11187-006-9003-4

Pentland, B. T., Feldman, M. S., Becker, M. C., \& Liu, P. (2012). Dynamics of organizational routines: A generative model. Journal of Management Studies, 49(8), 1484-1508. https://doi.org/10.1111/j.1467-6486.2012. 01064.X

Podolny, J. M., Stuart, T. E., \& Hannan, M. T. (1996). Networks, knowledge, and niches: Competition in the worldwide semiconductor industry, 1984-1991. American Journal of Sociology, 102(3), 659-689. https://doi.org/ 10.1086/230994

Ravichandran, T., Han, S., \& Mithas, S. (2017). Mitigating diminishing returns to $R \& D$ : The role of information technology in innovation. Information Systems Research, 28(4), 812-827. https://doi.org/10.1287/isre.2017.0717

Reynolds, P. D. (2000). National panel study of US business startups: Background and methodology. Advances in entrepreneurship, firm emergence and growth, 4(1), 153-227.

Reynolds, P. D., \& Curtin, R. (2007). Panel study of entrepreneurial dynamics II: Data overview. In 2007 Kauffman Symposium on Entrepreneurship and Innovation Data.

Reynolds, P., \& Miller, B. (1992). New firm gestation: Conception, birth, and implications for research. Journal of Business Venturing, 7(5), 405-417. https://doi.org/10. 1016/0883-9026(92)90016-K

Robb, A., Fairlie, R. W., \& Robinson, D. T. (2009). Patterns of financing: A comparison between White-and AfricanAmerican young firms-fourth in a series of reports using data from the Kauffman firm survey.

Robb, A. M., \& Watson, J. (2012). Gender differences in firm performance: Evidence from new ventures in the United States. Journal of Business Venturing, 27(5), 544-558. https://doi.org/10.1016/j.jbusvent.2011.10.002

Rodríguez-Pose, A., \& Crescenzi, R. (2008). Research and development, spillovers, innovation systems, and the genesis of regional growth in Europe. Regional Studies, 42(1), 51-67. https://doi.org/10.1080/003434007016541 86

Roodman, D. (2009a). How to do xtabond2: An introduction to difference and system GMM in Stata. (p. 121-136). Stata 
Journal, 9(1), 86-136. https://doi.org/10.1177/15368 67X0900900106

Roodman, D. (2009b). A note on the theme of too many instruments. Oxford Bulletin of Economics and Statistics, 71(1), 135-158.

Santos, F. M., \& Eisenhardt, K. M. (2009). Constructing markets and shaping boundaries: Entrepreneurial power in nascent fields. Academy of Management Journal, 52(4), 643-671. https://doi.org/10.5465/amj.2009.43669892

Schilling, M. A., \& Hill, C. W. L. (1998). Managing the new product development process: Strategic imperatives. The Academy of Management Executive, 12(3), 67-81. https://doi.org/10.5465/ame.1998.1109051

Schlesinger, L. A., \& Kiefer, C. F. (2012). Just start: Take action, embrace uncertainty, create the future. Harvard Business Review Press.

Schotter, A., \& Beamish, P. W. (2011). Performance effects of MNC headquarters-subsidiary conflict and the role of boundary spanners: The case of headquarter initiative rejection. Journal of International Management, 17(3), 243-259. https://doi.org/10.1016/j.intman.2011.05.006

Schwenk, C. R., \& Shrader, C. B. (1993). Effects of formal strategic planning on financial performance in small firms: A meta-analysis. Entrepreneurship Theory and Practice, 17(3), 53-64. https://doi.org/10.1177/10422 5879301700304

Shapiro, S. P. (2005). Agency theory. Annual Review of Sociology. https://doi.org/10.1146/annurev.soc.31.041304. 122159

Shepherd, D. A., \& Patzelt, H. (2013). Operational entrepreneurship: How operations management research can advance entrepreneurship. Production and Operations Management, 22(6), 1416-1422. https://doi.org/10. 1111/j.1937-5956.2011.01264.x

Simsek, Z., Fox, B. C., \& Heavey, C. (2015). "What's past is prologue" A framework, review, and future directions for organizational research on imprinting. Journal of Management, 41(1), 288-317. https://doi.org/10.1177/01492 06314553276

Singh, J. V., Tucker, D. J., \& House, R. J. (1986). Organizational legitimacy and the liability of newness. Administrative Science Quarterly, 171-193. https://doi.org/10. 2307/2392787

Sleptsov, A., \& Anand, J. (2008). Exercising entrepreneurial opportunities: The role of information-gathering and information-processing capabilities of the firm. Strategic Entrepreneurship Journal, 2(4), 357-375. https://doi.org/ 10.1002/sej.60

Smith, K. G., \& Cao, Q. (2007). An entrepreneurial perspective on the firm-environment relationship. Strategic Entrepreneurship Journal, 1(3-4), 329-344. https://doi.org/10. $1002 /$ sej.25

Spender, J. C., \& Kessler, E. H. (1995). Managing the uncertainties of innovation: Extending Thompson (1967). Human Relations, 48(1), 35-56. https://doi.org/10.1177/ 001872679504800103

Stevenson, H. H., \& Jarillo, J. C. (1990). A paradigm of entrepreneurship: Entrepreneurial management. Strategic Management Journal, 11, 17-27.

Swaminathan, A. (2001). Resource partitioning and the evolution of specialist organizations: The role of location and identity in the US wine industry. Academy of Management Journal, 44(6), 1169-1185. https://doi.org/10.2307/ 3069395

Tamura, S., Sheehan, J., Martinez, C., \& Kergroach, S. (2005). Enhancing the performance of the services sector. OECD Publishing.

Tatikonda, M. V., Terjesen, S. A., Patel, P. C., \& Parida, V. (2013). The role of operational capabilities in enhancing new venture survival: A longitudinal study. Production and Operations Management, 22(6), 1401-1415. https:// doi.org/10.1111/poms.12038

Thakur, T. N. (1999). Public sector: The road to freedom. Economic Times.

Thompson, J. D. (1967). Organizations in action: Social science bases of administrative theory. Transaction publishers.

Tracey, P., \& Dalpiaz, E. (2018). Fish out of water: Translation, legitimation, and new venture creation. (Business case study). Academy of Management Journal, 61(5), 16271666. https://doi.org/10.5465/amj.2015.0264

Tran, H. T. (2019). Institutional quality and market selection in the transition to market economy. Journal of Business Venturing, 34(5), 105890. https://doi.org/10.1016/j.jbusv ent.2018.07.001

Triana, M., Porter, C. O. L. H., Degrassi, S. W., \& Bergman, M. (2013). We're all in this together ... except for you: The effects of workload, performance feedback, and racial distance on helping behavior in teams. Journal of Organizational Behavior, 34(8), 1124-1144. https://doi. org/10.1002/job.1842

Tushman, M., \& Katz, R. (1980). External communication and project performance: An investigation into the role of gatekeepers. Management Science, 26(11), 1071-1085. https://doi.org/10.1287/mnsc.26.11.1071

Überbacher, F. (2014). Legitimation of new ventures: A review and research programme. Journal of Management Studies, 51(4), 667-698. https://doi.org/10.1111/joms.12077

Van de Ven, A. H., Venkataraman, S., Polley, D., \& Garud, R. (1989). Processes of new business creation in different organizational settings (pp. 222-226). Research on the management of innovation: The Minnesota studies.

Vermeulen, P. A. M., De Jong, J. P. J., \& O'Shaughnessy, K. C. (2005). Identifying key determinants for new product introductions and firm performance in small service firms. The Service Industries Journal, 25(5), 625-640. https://doi.org/10.1080/02642060500100783

Walker, E., \& Brown, A. (2004). What success factors are important to small business owners? International Small Business Journal, 22(6), 577-594. https://doi.org/10. 1177/0266242604047411

Weerts, D. J., \& Sandmann, L. R. (2010). Community engagement and boundary-spanning roles at research universities. The Journal of Higher Education, 81(6), 632-657. https://doi.org/10.1080/00221546.2010.11779075

Wennberg, K., Anderson, B. S., \& McMullen, J. (2019). 2 Editorial: Enhancing quantitative theory-testing entrepreneurship research. The Ratio Institute.

Whalley, A. E. (2011). Optimal R\&D investment for a riskaverse entrepreneur. Journal of Economic Dynamics and Control, 35(4), 413-429. https://doi.org/10.1016/j.jedc. 2009.11.009 
Wood, M. S., \& Mckinley, W. (2017). After the venture: The reproduction and destruction of entrepreneurial opportunity. Strategic Entrepreneurship Journal, 11(1), 18-35. https://doi.org/10.1002/sej.1238

Wooldridge, J. M. (2010). Econometric analysis of cross section and panel data. MIT press.

Wyld, D. C. (2010). Speaking up for customers: Can sales professionals spark product innovation? Academy of Management Perspectives, 24(2), 80-82. https://doi.org/10. 5465/amp.24.2.80

Xu, D., Zhou, K. Z., \& Du, F. (2019). Deviant versus aspirational risk taking: The effects of performance feedback on bribery expenditure and R\&D intensity. Academy of Management Journal, 62(4), 1226-1251. https://doi.org/ 10.5465/amj.2016.0749

Younger, S., \& Fisher, G. (2020). The exemplar enigma: New venture image formation in an emergent organizational category. Journal of Business Venturing. https://doi.org/ 10.1016/j.jbusvent.2018.09.002

Zeithaml, V. (1981). How consumer evaluation processes differ between goods and services. In Marketing of services (Vol. 9, pp. 186-190).

Zimmerman, M. A., \& Zeitz, G. J. (2002). Beyond survival: Achieving new venture growth by building legitimacy. Academy of Management Review, 27(3), 414-431. https://doi.org/10.2307/4134387

Publisher's note Springer Nature remains neutral with regard to jurisdictional claims in published maps and institutional affiliations. 